\title{
The importance and clinical relevance of surfaces in tissue culture
}

Graham J. Hickman, David J. Boocockץ, A. Graham Pockley†, and Carole C. Perry*

*carole.perry@ntu.ac.uk

Biomolecular \& Materials Interface Research Group, Nottingham Trent University, Clifton Campus, Clifton Lane, Nottingham, NG11 8NS, UK

$\dagger J o h n$ van Geest Cancer Research Centre, Nottingham Trent University, Clifton Campus, Clifton Lane, Nottingham, NG11 8NS, UK

KEYWORDS: tissue culture, surface chemistry, topology, extracellular matrix, cell response 
ABSTRACT: Cell and tissue culture has evolved from the use of simple glassware for the propagation of cells and tissues into a comprehensive platform for interrogating complex biological systems, directing cell fate and deriving products with clinical and therapeutic value. However, despite significant advances, current in vitro culture approaches remain limited in their capacity to model the clinical/biological complexities of disease, in part at least due to the deficiencies of existing culture materials. The challenge is therefore to identify innovative materials-based solutions that have greater control over cells in vitro, while better representing biological systems in vivo. Such platforms would be suitable for biomarker discovery and tissue engineering applications. This review examines the development of tissue culture materials, advances in our understanding of cell-surface interactions and the application of this knowledge towards the development of new approaches for better examining biological events. 
he ability to culture cells and tissues in vitro is a fundamental aspect of modern
science. Established early in the twentieth century, notably through the work of
Harrison R.G. of John Hopkins University ${ }^{1}$, the ability to culture cells and tissues has markedly improved during the intervening period. The field has progressed from an ability to maintain and culture tissue for extended periods, through the discovery and establishment of immortal cell lines, to today, where tissue engineering is making considerable progress in the

production of artificial tissues and organs in vitro ${ }^{2-4}$. Key to these successes have been advances in the culture surfaces on which cells and tissues are grown.

This review summarizes progress in the development of tissue culture materials, highlights current requirements and existing limitations for in vitro culture, and examines their relevance to clinical questions and our current understanding of tissue culture materials design. Although long-established, current culture materials may not always be appropriate for modelling in vivo conditions, and innovative strategies are therefore required in order to overcome existing limitations.

\subsection{Current Issues with Tissue Culture:}

Numerous articles have highlighted the drawbacks and limitations of current in vitro culture systems 5, 6 . Concerns revolve around deficiencies in the culture systems and the tissue they generate. Although the latter can be linked to the quality of the initial cellular material, contamination and/or poor maintenance of historical cell lines ${ }^{6,7}$, it can also result from deficiencies in the culture systems i.e. not all cell populations are amenable to in vitro culture. Problems are compounded once tissue enters in vitro culture, as derived populations are expected to maintain their in vivo relevance. However, cells naturally adapt to the local environment and 
prolonged culture of immortalized cell lines results in a progressive divergence from the parental population ${ }^{6,8,9}$. Although loss or gain of abnormal cell characteristics is a generic problem, it is more acute for cells exhibiting 'plasticity' such as stem cells, and the long term maintenance of pluripotency is recognized as a significant issue for stem cell research ${ }^{10}$. Taken together, it remains difficult to interpret the results of in vitro studies in the context of the in vivo situation. A practical example of this is the high rate of attrition for therapeutics, with less than $10 \%$ of candidates identified becoming licensed drugs ${ }^{11}$. The current consensus is that the failure rate for promising medical developments is, in part at least, attributable to the difficulty in translation of biocompatibility, toxicity or dose-responses that have been identified in vitro, into the in vivo setting ${ }^{12-14}$. 


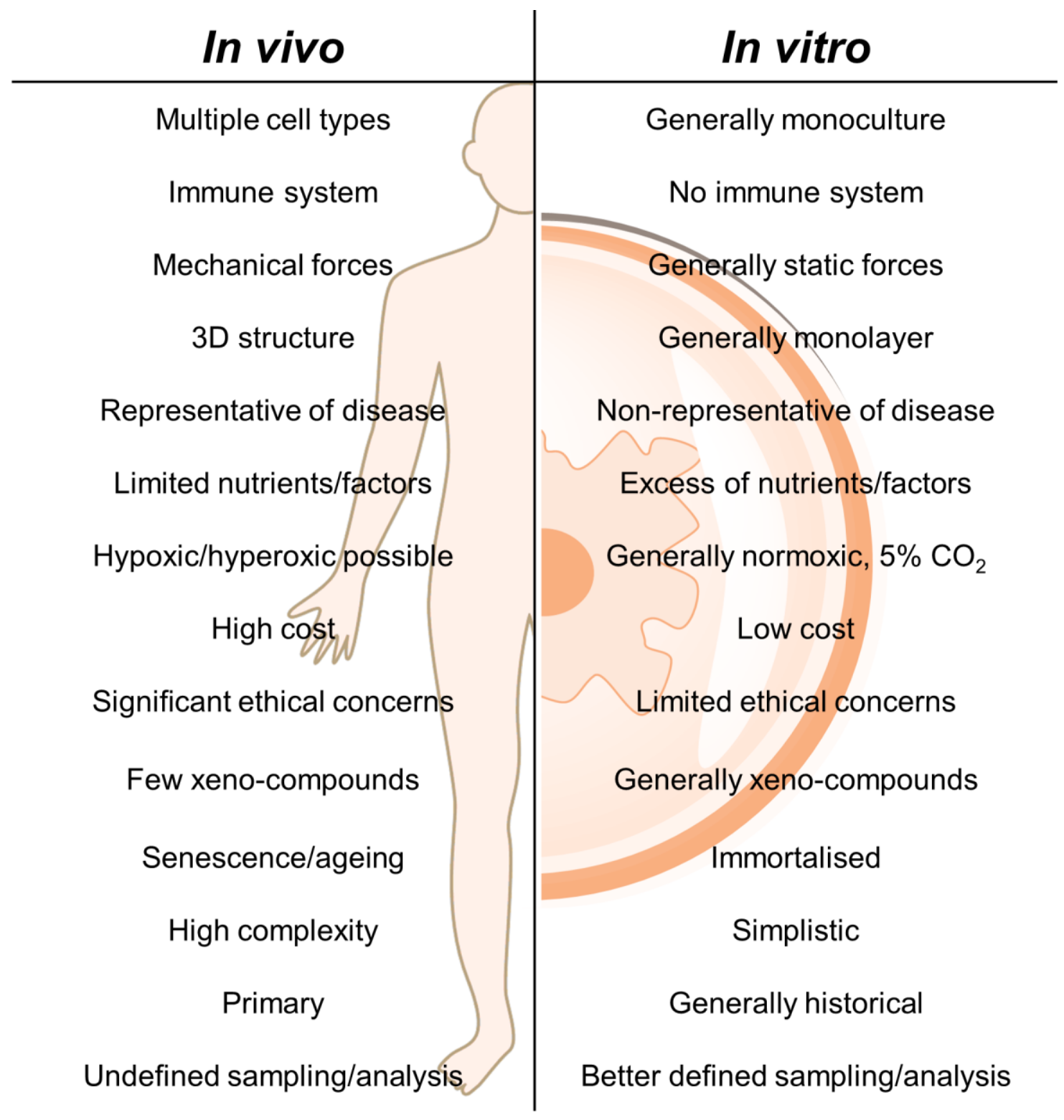

Figure 1. Comparing and contrasting the features of in vitro and in vivo tissue culture model systems.

Considering the problems, one might be prompted to favor in vivo model systems, Fig. 1. However, such systems are accompanied by ethical issues surrounding the use of animals, infrastructure, regulatory requirements and cost, and the data that they generate does not always reliably model or predict responses that occur in the clinical setting ${ }^{15}$, 16 . In vitro models therefore remain an important mainstay of biological and clinical research, with the development 
of novel in vitro models of in vivo biology having the potential to reduce the number of animals that are required for pre-clinical studies and therefore significantly impact on the application of the 3Rs (Replacement, Reduction and Refinement) principles ${ }^{17}$.

\subsection{Development of Tissue Culture Materials:}

2.1 From Glassware to Plastics: Early tissue culture materials evolved from glassware that was available in the laboratory at the time. Although glass is an adequate surface for culture, most adherent cells require the support of an extra-cellular matrix for adhesion and survival and so glass often required modification with a range of different biological polymers such as agar,

collagen, poly-L-lysine or cellulose in order to permit attachment and growth ${ }^{18-20}$. Many of the common matrix analogues or substitutes that have been used are summarized in Table 1. 


\begin{tabular}{|c|c|c|c|c|c|}
\hline Substrate & Role & Composition & Notes & Manufacturer & Reference \\
\hline Cellulose & Adherence & $\begin{array}{l}\beta(1-4) \text { linked D-glucose } \\
\text { polysaccharide }\end{array}$ & - & Various & 18 \\
\hline $\begin{array}{l}\text { CELLstart }^{\mathrm{TM}} \& \\
\text { MaxGel }^{\mathrm{TM}}\end{array}$ & $\begin{array}{l}\text { Defined ECM } \\
\text { homologue }\end{array}$ & $\begin{array}{l}\text { Human origin ECM } \\
\text { components }\end{array}$ & Xenobiotic free & $\begin{array}{l}\text { Invitrogen \& } \\
\text { Sigma } \AA\end{array}$ & 21 \\
\hline Collagen & $\begin{array}{l}\text { Adherence, } \\
\text { scaffold }\end{array}$ & $\begin{array}{l}\text { Protein family from } \\
\text { connective tissue, } 29 \\
\text { forms identified }\end{array}$ & $\begin{array}{l}\text { Matrix alternative, the } \\
\text { hydrolysate gelatin derives } \\
\text { from collagen }\end{array}$ & Various & 19,22 \\
\hline Entactins & Adherence & $\begin{array}{l}\text { Glycoprotein family of } \\
\text { the basement membrane }\end{array}$ & $\begin{array}{c}\text { Contains RGD adhesion } \\
\text { sequence }\end{array}$ & Various & 23 \\
\hline Fibronectin & Adherence & $\begin{array}{l}\sim 440 \mathrm{kDa} \text { ECM } \\
\text { glycoprotein }\end{array}$ & $\begin{array}{c}\text { Contains RGD adhesion } \\
\text { sequence }\end{array}$ & Various & 24 \\
\hline $\begin{array}{l}\text { Foetal bovine } \\
\text { serum }\end{array}$ & $\begin{array}{l}\text { Adherence, } \\
\text { proliferation }\end{array}$ & $\begin{array}{l}\text { Complex undefined } \\
\text { extract }\end{array}$ & High intra-batch variability & Various & 25 \\
\hline Laminins & Adherence & $\begin{array}{l}\text { Glycoprotein family of } \\
\text { the basement membrane }\end{array}$ & - & Various & 26 \\
\hline $\begin{array}{l}\text { Matrigel }^{\mathrm{TM}}, \\
\text { Geltrex } \AA \& \\
\text { Cultrex } \AA\end{array}$ & $\begin{array}{c}\text { ECM } \\
\text { homologue }\end{array}$ & $\begin{array}{l}\text { Biological extract of } \\
\text { proteins with growth } \\
\text { factors }\end{array}$ & $\begin{array}{l}\text { Derived from Engelbreth- } \\
\text { Holm-Swarm mouse sarcoma } \\
\text { cells }\end{array}$ & $\begin{array}{l}\text { BD Bioscience, } \\
\text { Trevigen, } \\
\text { Invitrogen }\end{array}$ & 27 \\
\hline$\varepsilon$-Poly-L-lysine & $\begin{array}{l}\text { Adherence, } \\
\text { scaffold }\end{array}$ & $\begin{array}{l}\text { Small ( }>20 \text { units) natural } \\
\text { homo-polypeptide of L- } \\
\text { lysine }\end{array}$ & $\begin{array}{l}\text { Bacteria derived, other homo- } \\
\text { polypeptides exist }\end{array}$ & Various & 20 \\
\hline Proteoglycans & Adherence & $\begin{array}{l}\text { Family of heavily } \\
\text { glycosylated ECM } \\
\text { proteins }\end{array}$ & $\begin{array}{l}\text { Grouped by } \\
\text { glycosaminoglycan e.g. } \\
\text { Agrin is a heparan sulphate }\end{array}$ & Various & 28 \\
\hline $\begin{array}{l}\text { StemAdhere } \\
\text { Vitronectin } \text { XFTM }^{\mathrm{TM}}\end{array}$ & Adherence & $\begin{array}{l}\text { Recombinant ECM } \\
\text { protein }\end{array}$ & Xenobiotic free & $\begin{array}{c}\text { Primorigen } \\
\text { Biosciences Inc. }\end{array}$ & 29 \\
\hline $\begin{array}{l}\text { StemXVivo }^{\mathrm{TM}} \& \\
\text { Synthemax } \\
\circledR\end{array}$ & $\begin{array}{l}\text { Defined ECM } \\
\text { homologue }\end{array}$ & $\begin{array}{l}\text { Recombinant ECM } \\
\text { proteins }\end{array}$ & Xenobiotic free & $\begin{array}{l}\text { R\&D Systems, } \\
\text { Corning }{ }^{\circledR}\end{array}$ & 29 \\
\hline Vitronectin & Adherence & $\begin{array}{l}\sim 75 \mathrm{kDa} \text { ECM } \\
\text { glycoprotein }\end{array}$ & $\begin{array}{c}\text { Contains RGD adhesion } \\
\text { sequence }\end{array}$ & Various & 24 \\
\hline
\end{tabular}

Abbreviations: ECM, extracellular matrix; RGD, Arginylglycylaspartic acid (RGD)

Today, glassware has been superseded by "plastic", organic polymers, which are considerably cheaper and more versatile. The principal polymer used is tissue culture polystyrene (TCPS). TCPS differs from conventional polystyrene in that the surface of the polymer is modified to more readily permit cell attachment and proliferation. This is achieved via the introduction of a range of different chemical functionalities such as carboxyl, hydroxyl, ketone or formyl groups 
to the surface using treatments such as sulphuric acid or oxygen plasma ${ }^{30}$. The nature of the functionality introduced influences surface performance in culture, an early observation was the preference in the hydroxyl component for BHK cell adhesion ${ }^{31}$. Surface treatment facilitates adhesion, and thus survival, by promoting the adsorption of extracellular matrix (ECM) components such as fibronectin and vitronectin from serum which is typically added to cell culture media, as well as the deposition of biomolecules that are endogenously produced during culture $^{31-34}$.

A wide range of culture materials and treatments have been developed since the introduction of TCPS, Fig. 2, examples are provided in Table 2. Advances in surface treatment techniques has allowed the production of surfaces with well-defined chemistries, such as the BD Purecoat ${ }^{\mathrm{TM}}$ series. This differs from conventional tissue culture plastic, in that surface functionality (be it amino or carboxyl) is of one type and tightly controlled ${ }^{35}$. 


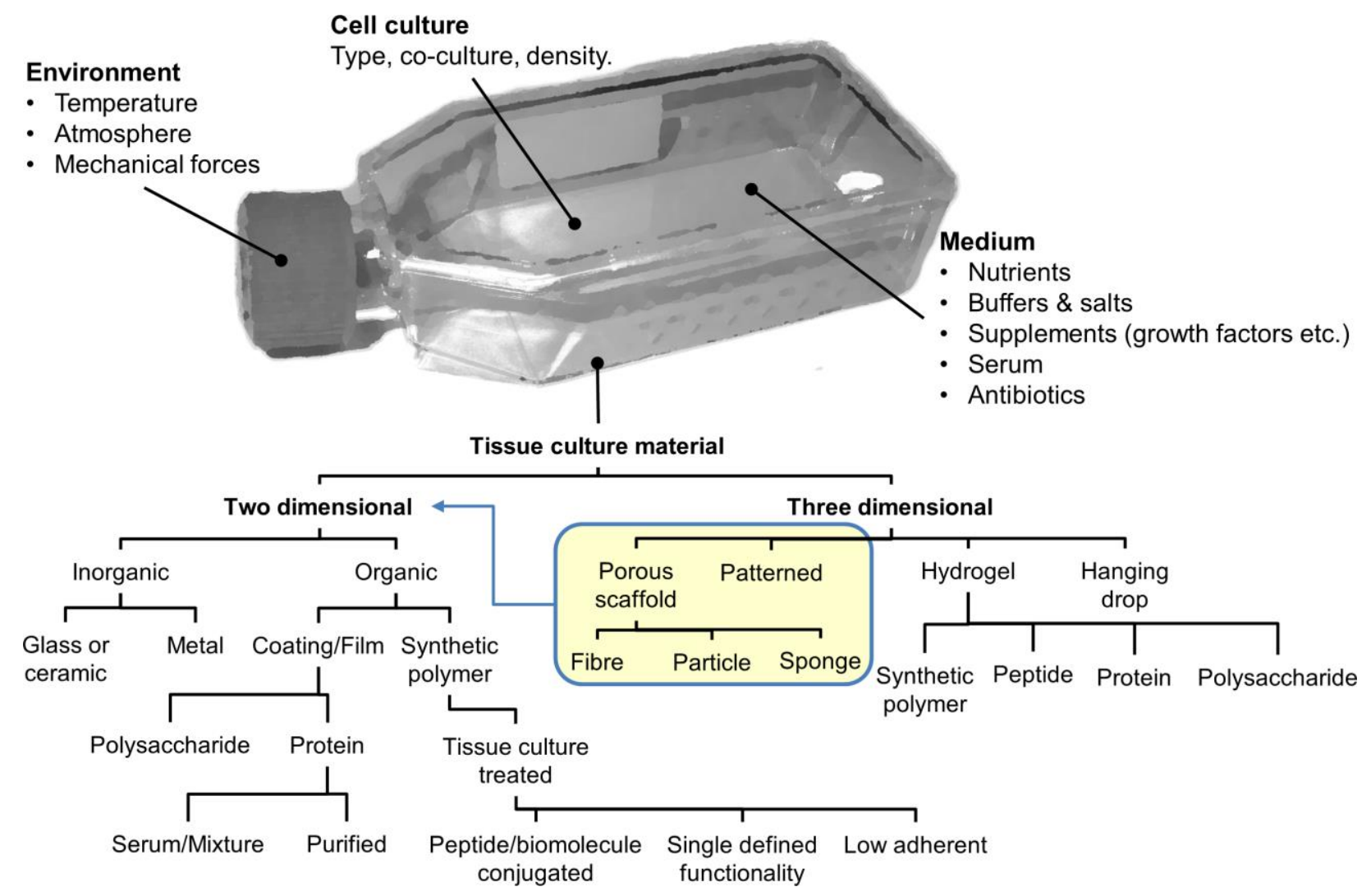

Figure 2. Different elements of in vitro culture systems. A scheme showing the different types of tissue culture material available is provided with examples given in Table 2. 
Table 2. Tissue culture materials

\begin{tabular}{|c|c|c|c|c|c|}
\hline Material & Role & Chemistry & Notes & Manufacturer & Reference \\
\hline Agar & $\begin{array}{l}\text { Adherent, } \\
\text { 3D culture }\end{array}$ & $\begin{array}{l}\text { Agarose and agaropectin } \\
\text { polysaccharide }\end{array}$ & - & Various & 18 \\
\hline AlgiMatrix ${ }^{\circledR}$ & $\begin{array}{l}\text { 3D tissue } \\
\text { culture }\end{array}$ & Polysaccharide & Alginate based scaffold & Invitrogen & 36 \\
\hline Alvetex ${ }^{\circledR}$ Scaffold & $\begin{array}{l}\text { 3D tissue } \\
\text { culture }\end{array}$ & $\begin{array}{l}200 \mu \mathrm{m} \text { porous polystyrene } \\
\text { membrane }\end{array}$ & $\begin{array}{l}\text { Pore diameter is } 40 \mu \mathrm{m} \\
\text { with interconnects of } \\
13 \mu \mathrm{m}\end{array}$ & Reinnervate & 36 \\
\hline BD PureCoat ${ }^{\mathrm{TM}}$ & $\begin{array}{l}\text { Adherent } \\
\text { culture }\end{array}$ & Surface treated polystyrene & Single functionalities & BD Bioscience & 35 \\
\hline $\begin{array}{l}\text { BD PureCoat } \\
\text { ECM Mimetic \& } \\
\text { Synthemax }^{\mathrm{TM}}\end{array}$ & $\begin{array}{l}\text { Adherent } \\
\text { culture }\end{array}$ & Peptide conjugated polystyrene & $\begin{array}{l}\text { Modified with synthetic } \\
\text { peptides e.g. fibronectin } \\
\text { and collagen I }\end{array}$ & $\begin{array}{l}\text { BD Bioscience, } \\
\text { Corning }{ }^{\circledR}\end{array}$ & 37 \\
\hline $\begin{array}{l}\text { Corning }{ }^{\circledR} \text { Osteo } \\
\text { Assay Surface }\end{array}$ & $\begin{array}{l}\text { Adherent } \\
\text { culture }\end{array}$ & $\begin{array}{l}\text { Patterned tissue culture } \\
\text { polystyrene }\end{array}$ & $\begin{array}{l}\text { Assess osteoclast \& } \\
\text { osteoblast functionality }\end{array}$ & Corning ${ }^{\circledR}$ & 38 \\
\hline Glass & $\begin{array}{l}\text { Adherent } \\
\text { culture }\end{array}$ & Borosilicate glass & $\begin{array}{l}\text { Acid treatment was } \\
\text { common }\end{array}$ & Various & 24 \\
\hline Hyaluronan & $\begin{array}{l}\text { 3D tissue } \\
\text { culture }\end{array}$ & $\begin{array}{l}\text { Polysaccharide of D-glucuronic } \\
\text { acid and D-N- } \\
\text { acetylglucosamine, }>20 \\
\text { million Da }\end{array}$ & $\begin{array}{l}\text { Hydrogels with differing } \\
\text { chemistry such as growth } \\
\text { factor release }\end{array}$ & Various & 36 \\
\hline HydroMatrix $^{\mathrm{TM}}$ & $\begin{array}{l}\text { 3D tissue } \\
\text { culture }\end{array}$ & Peptide hydrogel & - & Sigma ${ }^{\circledR}$ & 39 \\
\hline Hydroxyapatite & $\begin{array}{l}\text { Adherent } \\
\text { culture }\end{array}$ & Calcium phosphate mineral & Indicates bioactivity & Various & 40 \\
\hline $\begin{array}{l}\text { Perfecta3D } \AA \& \\
\text { GravityPLUS }\end{array}$ & $\begin{array}{l}\text { 3D tissue } \\
\text { culture }\end{array}$ & None & $\begin{array}{l}\text { Hanging drop for } \\
\text { spheroid culture }\end{array}$ & $\begin{array}{l}\text { 3D Biomatrix, } \\
\text { InSphero }\end{array}$ & 41 \\
\hline Polyacrylamide & 2D hydrogel & Polyacrylamide hydrogel & - & Various & 42 \\
\hline Polycaprolactone & $\begin{array}{l}\text { 3D tissue } \\
\text { culture }\end{array}$ & Polycaprolactone & Biodegradable & Various & 36 \\
\hline $\begin{array}{l}\text { Polyethylene- } \\
\text { Glycol, QGel }^{\mathrm{TM}}\end{array}$ & $\begin{array}{l}\text { 3D tissue } \\
\text { culture }\end{array}$ & Polyethylene glycol hydrogel & $\begin{array}{l}\text { Differing chemistry such } \\
\text { as light sensitivity or } \\
\text { biodegradable }\end{array}$ & Various, QGel & 36 \\
\hline $\begin{array}{l}\text { Polystyrene } \\
\text { (TCPS) }\end{array}$ & $\begin{array}{l}\text { Adherent } \\
\text { culture }\end{array}$ & Surface treated polystyrene & $\begin{array}{l}\text { Single or mixed surfaces } \\
\text { chemistry }\end{array}$ & Various & 31 \\
\hline $\begin{array}{l}\text { TCPS low } \\
\text { adherence }\end{array}$ & $\begin{array}{l}\text { Low } \\
\text { adherence }\end{array}$ & Hydrophilic, neutral charge & Corning ${ }^{\circledR}$ use hydrogel & Various & 43 \\
\hline
\end{tabular}

Changes in culture practice, such as the more widespread use of serum supplementation and the availability of new materials have, to some degree, eliminated the requirement for pre-treatment 
with ECM analogues/substitutes such as collagen. However, challenging applications such as the culture of primary cell lines having a limited proliferative capacity and stem cells continue to require pre-treatment strategies ${ }^{29}$. Our increased understanding of cell adhesion and its requirements has increased the range of naturally-derived or recombinant proteins that can be used for the pre-treatment of culture surfaces (see Table 1).

The discovery of cell adhesion molecules (CAMs) and their role in cell-cell and cell-surface interactions has led to the development of surfaces incorporating the principals of cell adhesion and the ECM such as the BD PureCoat ${ }^{\mathrm{TM}}$ ECM Mimetic \& Synthemax ${ }^{\mathrm{TM}}$ surfaces ${ }^{44}$. These are chemically functionalized with peptides derived from the active sites of proteins that are implicated in cell adhesion, such as the tripeptide arginylglycylaspartic acid (RGD) ${ }^{45}$. The RGD sequence is implicated in cellular attachment via integrins (such as $\alpha_{5} \beta_{1}$ and $\alpha_{v} \beta_{3}$ ), ${ }^{46}$ and can be used to coat synthetic scaffolds in order to enhance cellular attachment by mimicking in vivo conditions.

Patterning of surfaces using lithography, chemical or mechanical processes has also been used to yield better mimics of in vivo environments ${ }^{47}$. For example, the Corning ${ }^{\circledR}$ Osteo Assay Surface has been modified with a synthetic crystalline calcium carbonate coating in order to better resemble the surface of bone for assessing the performance of osteoclasts and osteoblasts ${ }^{48}$.

2.2 Advanced Tissue Culture Concepts: Building on the principals of matrix substitutes and advanced surface chemistry, a range of advanced tissue culture concepts have emerged. Many advanced tissue culture systems have moved towards the presentation of an artificial ECM, initially via the presentation of biologically-derived ECM components, for example Matrigel ${ }^{\mathrm{TM}}$ 27. More recently, substitutes that are artificial in nature (e.g. SemXVivo ${ }^{\mathrm{TM}}$ ) have been developed 
and these benefit from being chemically defined and free from xeno (other species-related) components ${ }^{29,36}$.

Parallel to the development of xeno-free ECM mimics has been the introduction of serum-free (not necessarily protein- or peptide-free - although these also exist) media systems ${ }^{49}$. Serum is problematic in that it is poorly defined with batch-to-batch variations in its ability to sustain the growth of different cell populations and sub-populations. Although the concept of serum-free culture has existed for a long time, its implementation has been difficult. The removal / absence of serum components can trigger apoptosis of cells in culture. Although certain neuronal cell lines have been adapted to serum-free media, success with other lines remains elusive, not least due to the complexity of individual line requirements ${ }^{50}$.

Although there have been significant advances in cell culture technologies, the adoption of advanced culture systems continues to be poor. For example, the Google Scholar search 'tissue culture "purecoat" returned 61 entries in total, "tissue culture "polystyrene" returned 2,400 entries for the first five months of 2015 alone. This disparity can, perhaps, be understood by the niche application of specialist materials and the established nature of existing materials such as TCPS which offers acceptable performance for most applications. Although the issue of in vitro relevance could progressively be resolved by ever increasingly complex in vitro systems, such systems would be progressively more difficult to standardize and validate, and would likely be poorly adopted based on the uptake of even the modest advancements that are currently available (though these have not always had such well-defined applications or requirements).

2.3 Three Dimensional Culture Systems: The concept that the culture environment should closely replicate in vivo conditions now incorporates the view that tissue culture surfaces should 
no longer be 'flat' surfaces. Although '3D' materials have existed for some time (e.g. agar), considerable interest in the application of 3D tissue culture systems has developed and these platforms are now becoming more widely employed, with a multitude of different methods for achieving such materials having being developed (see Table 2 and Fig. 2) ${ }^{51,52}$. Cells proliferate and migrate within and atop these $3 \mathrm{D}$ materials and those such as hydrogels can approximate biological structures such as the ECM while displaying 'smart' properties such as an ability to respond to culture conditions and external stimuli ${ }^{53}$. The interest in the field has generated many informative reviews of $3 \mathrm{D}$ culture systems $36,54,55$, with an emphasis on hydrogels as mimics for extracellular matrix ${ }^{56}$.

Relevant to our emphasis on surface chemistry is another example of 3D culture; spheroids. These require cells to culture independently of adhesion to the surface and the generation of which relies on low adherence culture materials.. These can be achieved by 'passivation' of a surface using, for example, a hydrophilic, neutrally charged hydro-gel layer that prevents protein uptake and cell adhesion. Other non-adherent systems use only the air/liquid interface which is formed through surface tension ${ }^{41,43}$. Spheroid cultures are popular in vitro models due to their emphasis on cell-cell interactions and the secreted microenvironment, such approaches can also be used as a platform for generating complex $3 \mathrm{D}$ tissues ${ }^{57}$.

A trend throughout the development of new tissue culture materials for applications ranging from tissue engineering to cancer research has been to apply our increasing understanding of the in vivo microenvironment to develop materials with local culture environments that are ever more representative of the in vivo conditions ${ }^{58}$. If the problem of in vitro relevance can partly be attributed to deficiencies such as existing culture systems not mimicking in vivo conditions, then it is unsurprising that, when conditions are modified to better reflect conditions in vivo, different 
morphological, proliferative and dose responses to therapeutic drugs are noted ${ }^{59}$. As such, it is worth re-examining our conceptual understanding of a tissue culture surface.

\subsection{Defining a Model of Cell Surface Interaction:}

Tissue culture materials are all too often considered as merely a surface on which cells grow. Cell surface interactions can be difficult to visualize, as they encompass a complicated three dimensional arrangement and interaction of a multitude of different molecules and structures (both biological and non-biological) that operate on different length and time scales. A pictorial representation of cell-surface interactions and some of the processes involved is shown in Fig. 3A-F. 


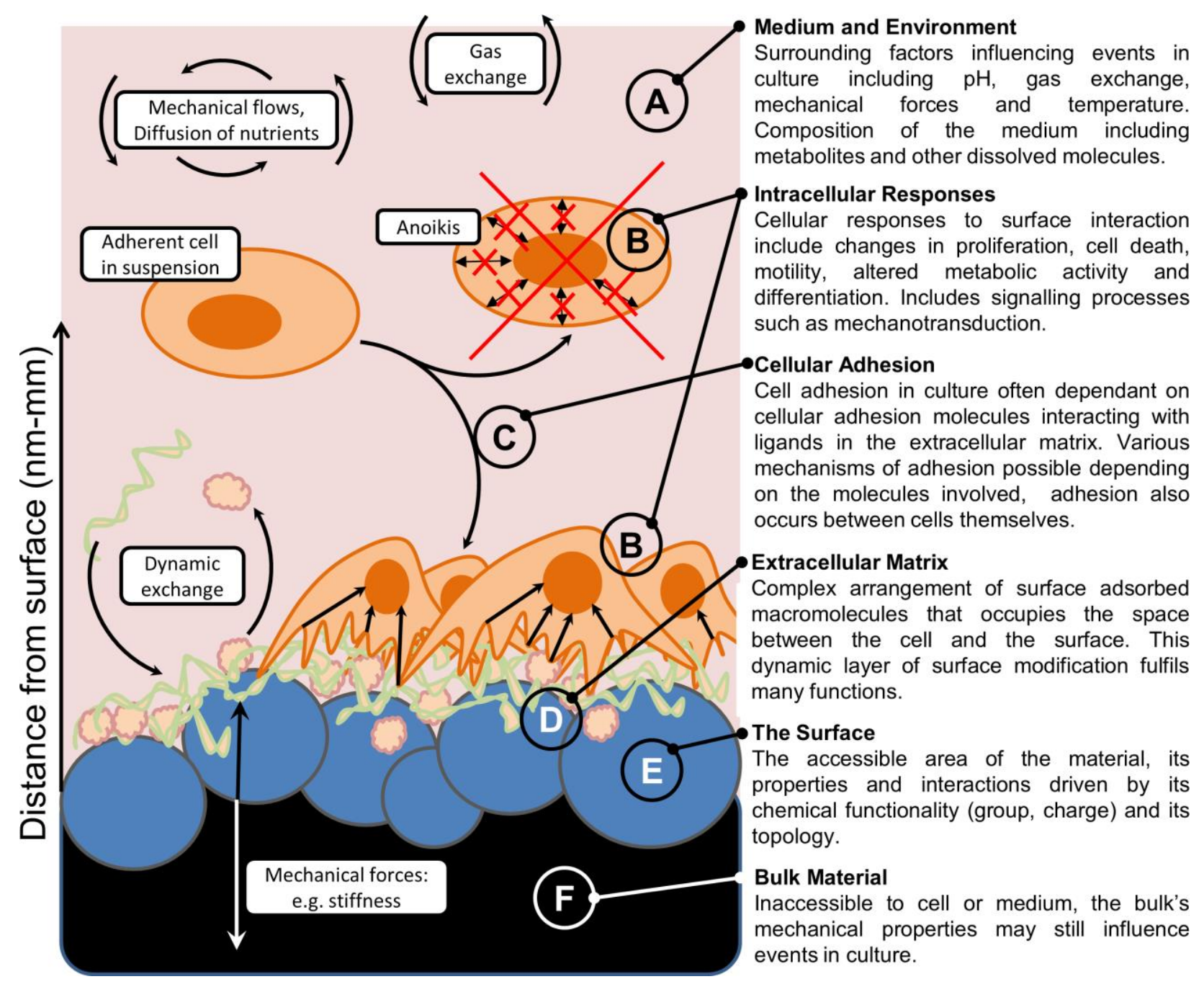

Figure 3. Model of adherent cell culture and representation of some of the factors and influences on the cell. The various elements represent; A: medium and surrounding environment, B: cell body and response, C: cell adhesion, D: protein adsorption (ECM), E: accessible surface, F: bulk substrate.

3.1 The Medium \& the Environment (A): Cell surface interactions involve an extracellular component between cell and surface and intracellular components that are modified as a result of surface interaction; the cell's response. Events on the surface (such as protein adsorption) will be influenced to a large degree by the surrounding environment such as composition of the medium and environmental factors (temperature, pressure, $\mathrm{CO}_{2}$ concentration etc.), Fig. 3A. Tissue culture media themselves are complex compositions of salts, metabolites and potentially dyes, 
antibiotics as well and undefined mixtures of proteins, metabolites and signaling molecules of biological origin ${ }^{26}$. All of these elements contribute to the significant complexity of the culture surface under different conditions.

3.2 Intercellular Implications of Cell-Surface Interaction (B): The presence or lack of contact with surfaces (or rather surface adsorbed biomolecules) has a significant effect on a wide range of cell behaviors, including motility, morphology, proliferation and differentiation, Fig. 3B ${ }^{60}$. Motility, as a response to a stimulus or as a process in the pathology of disease and its spread (for example anoikis and metastasis) involves dynamic interactions of the cell cytoskeleton with the underlying extra-cellular matrix (ECM), permitting cell relocation ${ }^{61,62}$.

Adhesion is a matter of life and death for anchorage-dependent cell types, as cells unable to attach to the ECM undergo a form of programmed cell death called anoikis ${ }^{63}$. Without the formation of cytoskeletal elements associated with ECM adhesion, cell death is induced through caspase signal transduction and, when adhesion site components such as focal adhesion kinase are compromised, DNA synthesis is inhibited ${ }^{64,}{ }^{65}$. Conversely, attachment promotes proliferation through cell division, with focal adhesion being implicated in many cell proliferation pathways such as the focal adhesion kinase and extracellular-signal-regulated kinase mediated pathways ${ }^{66}$.

Cell surface interactions have been demonstrated to play an important role in cell fate, as they can modify the capacity of cells to undergo differentiation or maintain pluripotency ${ }^{67,}{ }^{68}$. The mechanism of translating perturbations to the cytoskeleton into cell responses is known as 'mechanotransduction' ${ }^{69}$, in which forces exerted on the cytoskeleton of the cell and changes in the availability of binding sites for cell adhesion molecules due to surface features influence the 
biochemical pathways of the cell ${ }^{70}$. As an example, mechanical perturbation of cells can induce expression of the transcription factor Twist and differences in ECM stiffness are associated with the process of tissue differentiation ${ }^{71}$.

Several biochemical pathways have been identified as having a role in mechanotransduction. The transcription coactivators YAP/TAZ have been implicated in sensing cytoskeletal tension, their activity is modulated by mechanical inputs, inputs which can be overruled if YAP/TAZ activity is manipulated artificially ${ }^{72}$. This activity is independent from many elements of the Hippo signaling pathway and instead depends on Rho GTPase activity and actinomyosin, though YAP/TAZ are associated with multiple inputs ${ }^{72,}{ }^{73}$. Key sensory molecules in mechanotransduction include the cytoskeletal elements as noted above but also G-protein coupled receptors, growth factor receptors and stretch activated ion channels ${ }^{71}$. In addition to YAP/TAZ these sensory elements relay extracellular cues into pathways such as MAPK ${ }^{71,74}$ and P13K/Akt ${ }^{75}$.

Mechanotransduction can be actively exploited to induce cell responses via, for example, controlling substrate stiffness ${ }^{76}$, or topology ${ }^{77}$. The ability to precisely measure forces at the substrate, the plasma membrane and in the cytoskeleton is a significant aid in unravelling the influence that mechanical forces and their inducement have on cellular responses ${ }^{78}$.

3.3 Cellular Adhesion (C): The next component of the model involves cellular interactions with extra-cellular molecules that have been adsorbed on to the cell surface - the process of cell adhesion, Fig. 3C. Protein adsorption is considered to be an essential pre-requisite for cell adhesion, with multiple components of the ECM playing a role. These include proteins such as collagen, vitronectin and fibronectin, all of which have been known to enhance cell adhesion to 
surfaces for some considerable time ${ }^{24}$. However, certain proteins are more relevant than others, and their specificity is dependent on individual cell type. As an example, the adhesion and proliferation of bovine corneal and arterial cells is impaired in cultures lacking vitronectin ${ }^{24}$.

Cell adhesion to surface adsorbed ECM proteins is facilitated by cell adhesion molecules (CAMs) such as the calcium-dependent class of adhesion molecules known as integrins ${ }^{79}$. The ECM contains an abundance of amino-acid motifs with pro-adhesion effects; the best characterized being the RGD sequence, a ligand for $\alpha_{v} \beta_{3}$ integrin receptors for example ${ }^{67,80}$. The modification of surfaces to present this sequence (e.g. covalently grafted using Nhydroxysuccinimide) enhances focal adhesion and induces the differentiation of adherent cells such as osteoblasts ${ }^{80-82}$. Focal adhesion encompasses large and dynamic macromolecular assemblies comprising many individual integrin receptors and their associated proteins ${ }^{61,83}$.

Adhesion is not a guaranteed outcome of cell-protein-surface interaction, as stable attachment cannot occur when surfaces cannot support CAMs ${ }^{84,85}$. Other cell adhesion processes such as anchoring, and the establishment of tight and gap junctions are associated with cell-cell rather than cell-surface adhesion ${ }^{86}$. In tissue culture design, cell-cell interactions can be just as important, or of greater importance, than cell surface interactions such as in spheroid formation using 3D culture and the study of cell aggregation and disaggregation processes like metastasis $57,87$.

3.4 Extracellular Matrix; Biological Surface Modification (D): Cell-protein interactions are, in part, dictated by the properties of the surface; its ability to absorb the ECM and the nature of the ECM supply in the culture environment e.g. supply of CAMs in the media ${ }^{88,89}$. Cell responses such as surface adhesion and subsequent differentiation are the result of interactions 
between the surface of the material and the macromolecules that adsorb to the surface, and are influenced by the surrounding environment or 'niche' ${ }^{84,89}$. The nature of the ECM reflects the broad range of biomolecules such as proteoglycans, polysaccharides, fibrous proteins like collagens and adhesion proteins such as fibronectin and vitronectin that are available ${ }^{90}$.

Macromolecules such as proteins and carbohydrates are important constituents of most biological media and will adsorb to the surface over time, displacing bound water, ions and other smaller species. This adsorption process starts almost immediately the material enters the biological environment ${ }^{91}$. The process is also dynamic, with the surface adsorbed layer being continually remodeled as conditions change, for example through the Vroman effect, a process by which fast binding protein species on the surface are exchanged with other species of higher surface affinity over time ${ }^{92}$.

Physiologically, the ECM occupies the space between cells and is the primary constituent of connective tissue ${ }^{93}$. The role of the ECM is as diverse as its constituents, and its functions include, but are not limited to, acting as a shock absorber, scaffold, store of energy and signaling molecules and finally as a site for cell attachment ${ }^{93}$. In the laboratory, the adsorbed macromolecules act as a dynamic layer of surface modification, altering the chemistry and topology of the surface, with this modification being influenced by the properties of the surface itself (a Smart material!). Properties of the surface such as its topology can alter macromolecule loading and characteristics such as the secondary structure and orientation of proteins, which can vary from molecule to molecule, and surface to surface ${ }^{94-96}$.

This dynamic environment and the formation of the ECM is heavily influenced by proteins that are provided as a consequence of serum supplementation, as well as those that are produced by 
the cells themselves. This diverse mixture of proteins, metabolites and other molecules is generally poorly defined both initially and during culture.

3.5 The Surface; between the Bulk Material \& Medium (E): The penultimate layer of the model is the surface itself (Fig. 3E). Although at its simplest, this can be described as being no more than the top-most layer of accessible atoms, exact definitions are difficult as it varies depending on the interacting molecule. For example, the covalent radius of a hydrogen atom is $25 \mathrm{pm}$, but for a sodium atom this is $180 \mathrm{pm}^{97}$. As a consequence, the two atoms will describe a given surface differently. This holds true for larger molecules, in that the form of the surface, its topology and porosity (Fig. 3F) all affect how molecules will interact with the surface and contribute to the bulk surface properties such as wetting ${ }^{98,99}$. Tissue culture materials have a wide variety of forms depending on the processing methods used, Table 2.

Whatever the 'surface' is considered to be, the intra-molecular interactions it promotes strongly affect the surface properties exhibited. In the case of tissue culture polystyrenes, the surface is comprised of hydrocarbon chains containing exposed phenyl groups and a mixture of various oxygen (e.g. hydroxyl or carboxyl) or nitrogen (e.g. amine) containing groups, and different processing can vary their relative composition ${ }^{100}$. The introduction of polar species to polystyrene permits hydrogen bonding and electrostatic interactions, both of which influence solvation. Depending on solvent composition and surface properties, other entities such as counter-ions may also be present. In the biological context, most surfaces adsorb a wide variety of biomolecules such as proteins from a media.

There has been a push in recent years to move away from $2 \mathrm{D}$ culture systems, and this has been prompted by strong arguments in terms of biological relevance ${ }^{51,59}$. It is worth appreciating at 
this point that the distinction between 2D and 3D materials becomes immaterial as the molecular scale decreases. This is not to disparage 3D materials, providing many $2 \mathrm{D}$ regions of interaction and arranging them in a defined (or undefined) manner around the cell clearly influences cell

response ${ }^{54,59}$. The mechanisms governing how surface properties influence protein adsorption and hence cell response in $2 \mathrm{D}$ materials should translate to $3 \mathrm{D}$. The difficulty in precise characterization of surfaces in $3 \mathrm{D}$ e.g. molecular orientation within a gel, suggests that $2 \mathrm{D}$ materials still have an important role to play in the development of new tissue culture materials and that the rush for 3D 'effects' should not come at the expense of our fundamental understanding of the principals operating in 2D. A comprehensive understanding of these phenomena is currently missing and considerable work is required to show how surface properties (chemistry and topology) guide protein adsorption and as a result induce cellular responses.

\subsection{Tissue Culture Surfaces as Tools to Control Cell Response: Investigations of} cell-protein-material responses have been performed using a wide range of materials and cell types, and a number of reviews concerning the responses of specific cell types such as neuronal ${ }^{101}$ and antigen presenting cells have now been published ${ }^{102}$.

4.1 The Influence of Topology: Early observations identified the ability of topological features to guide the morphological organization of cell populations in terms of alignment and elongation, a phenomenon known as 'contact guidance' ${ }^{103}$. Later studies expanded on the influence of topology on proliferation, adhesion and, as interest in cell lines important for tissue regeneration (e.g. transient stem cell populations) increased, topological features that confer control over cell 
renewal and differentiation have been identified ${ }^{104-106}$. Fig.4 illustrates the scale at which different cellular and protein responses have been observed.

Topology has been explored in a controlled manner, principally by using organic polymer materials and techniques such as lithography for 2D and electrospinning for 3D materials, both of which allow fine control of the structure on the micron to nano scale ${ }^{107}$. A broad range of materials encompassing most major classes of plastic, including biodegradable polymers such as polycaprolactone, have now been examined ${ }^{10}$. Responses over scales of a few nanometers (surface roughness) to hundreds of microns have been explored, and the effect of feature shape, size, orientation and density within these range of scales, Fig. 4, have been considered. Mechanical properties such as stiffness have also been assessed ${ }^{108}$.

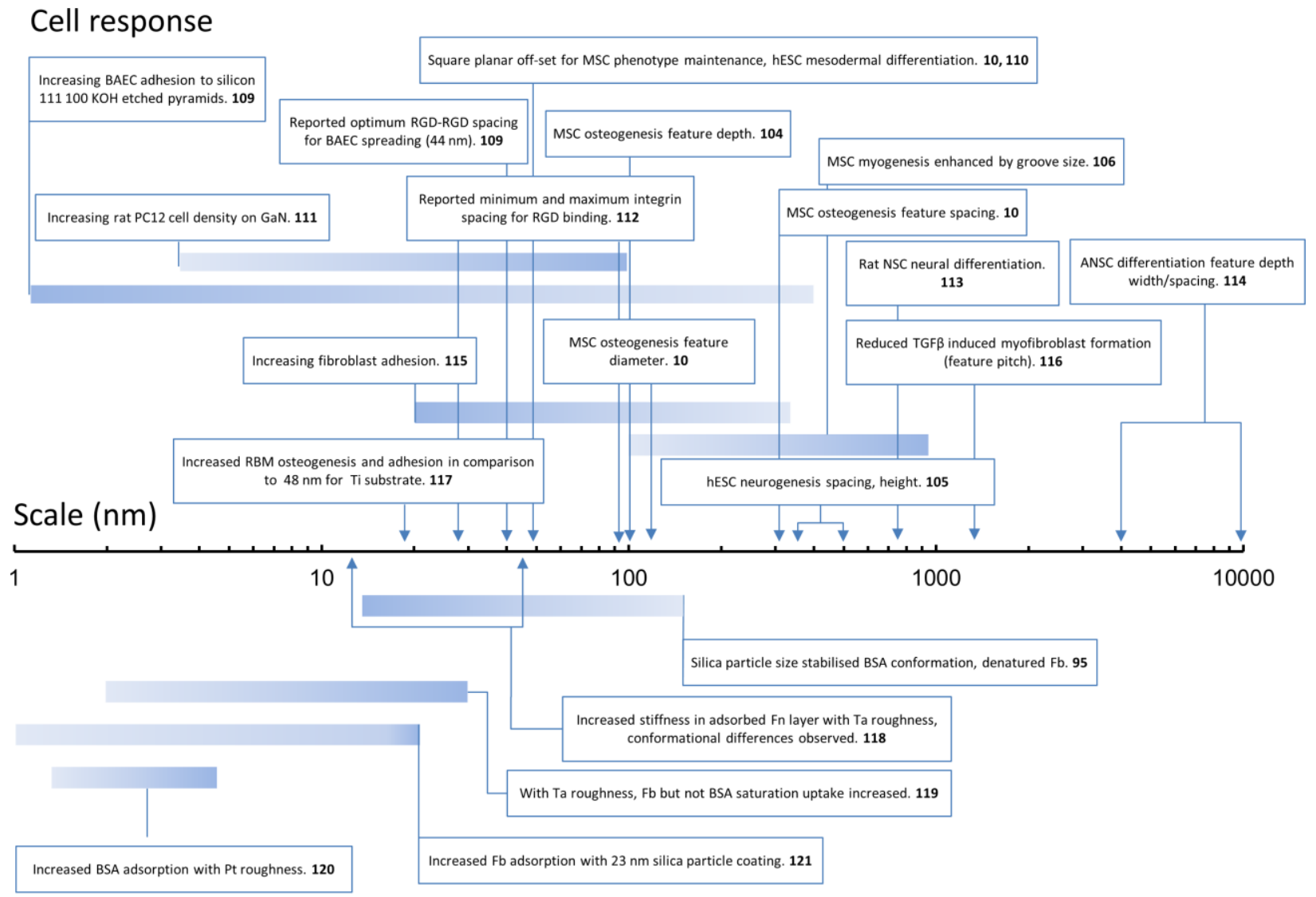

Protein response 
Figure 4. Influence of surface topological features at different scales on both the protein microenvironment and cell response. Bars with shaded gradients show cell and protein response across a range of topological sizes.

Above one micron, cellular responses are generally defined via contact guidance, with phenomena such as axon outgrowth processes noted at the 'smaller features' of the topology, e.g. edge effects ${ }^{122}$. As the scale of surface topological features (pits, islands, columns and gratings) decreases to the range of several hundred to several tens of nanometers, a plethora of cellular responses, across the full range of cell and material types (Fig. 4) is obtained, for example, cellsurface adhesion increases $106,109,115$. Studies on a variety of cell lines and surfaces have shown that neurite outgrowth in the presence of nerve growth factor is enhanced by channels $70-250 \mathrm{~nm}$ in width with a fixed depth of 300-600 nm ${ }^{122,123}$. However, cell responses to topology are not always linear, and may be cell type-dependent (e.g. fibroblasts vs. mesenchymal cells) ${ }^{104}$.

For 'plastic' populations such as mesenchymal stem cells (MSCs), differentiation effects such as osteogenesis or neurogenesis have been observed across the scale ${ }^{105,111,114}$. Feature size dependent effects have been observed, such as rat neural stem cell oligodendrocyte differentiation, proliferation and aggregation being favored for smaller electrospun polysulphone fibers (range examined was $283-1452 \mathrm{~nm} \emptyset)$, whereas intermediate $(\sim 749 \mathrm{~nm})$ or larger fibers favor neuronal differentiation ${ }^{113}$. Alignment and differentiation (adipogenesis and myogenesis) of rat MSCs has been shown to be influenced by grooved surfaces (width/depth of 450/100, $450 / 350,900 / 100$ and $900 / 550 \mathrm{~nm})$, the latter in a groove size dependent manner ${ }^{106}$. Fewer observations have been reported for experiments performed using topological features smaller than 20 nanometers (Fig, 4), and these suggest that the ability of cells to sense topological changes at this scale becomes more limited ${ }^{112,115}$. However, at this lower end of the topology 
length scale, topological features are known to drive increased adsorption and deformation in the protein microenvironment, Fig. $4^{119-121}$.

Studies on single size features within the range of one micron to tens of nanometers, have identified specific cell responses such as the transition of embryonic cells to a neuronal phenotype in the absence of traditional chemical agents being induced by polyurethane acrylate ridges/grooves of $350 \mathrm{~nm}$ spacing and $500 \mathrm{~nm}$ height ${ }^{105}$. In addition to inducing differentiation, the maintenance of MSCs for extended periods has been demonstrated using $150 \mathrm{~nm}$ polycaprolactone pits with a $300 \mathrm{~nm}$ square planar spacing. However, and in contrast, pits offset from a square planar arrangement by $50 \mathrm{~nm}$ enhance osteogenesis ${ }^{10}$. The apparent importance of these relatively discrete changes in topology on cell response highlight the complexity of topology-related responses, as well as the difficulty in interpreting a multitude of experimental observations that are taken under very disparate conditions.

4.2 The Influence of Surface Chemistry: The influence of chemical functionality has been primarily explored using self-assembled monolayers (SAM), as this approach can achieve a uniform loading of the desired functionality ${ }^{96,124}$. Fig.4 illustrates the relationship between water contact angle and cellular and protein responses that have been observed for a number of surface chemistry studies. A range of functionalities have been studied (Fig. 5, Table 4) and, similarly to topological studies, work has focused on cells of a plastic nature that are applicable to tissue engineering. 


\section{Cell response}

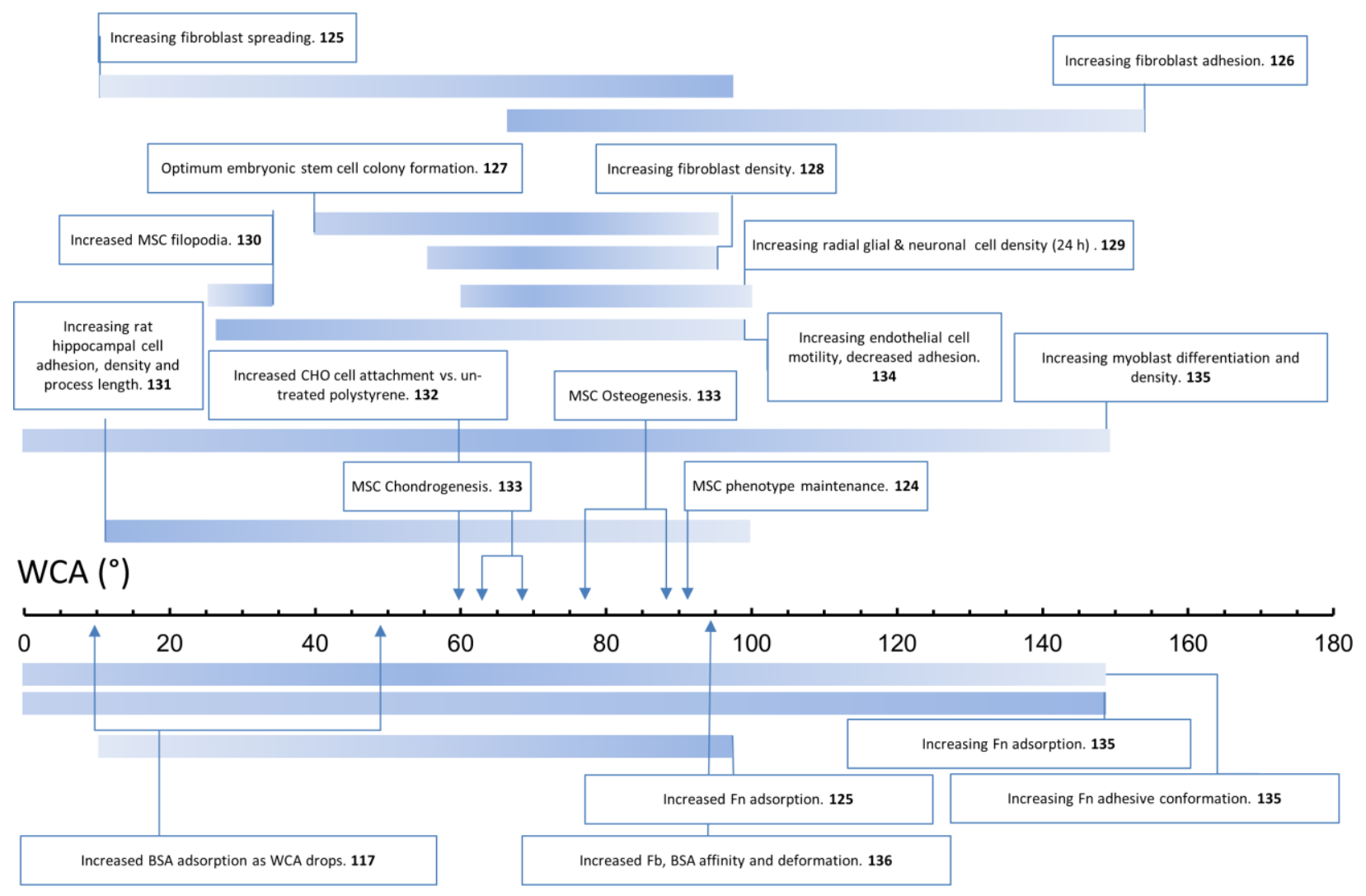

\section{Protein response}

Figure 5. Influence of water contact angle (WCA) for a range of chemically distinct materials on both the protein microenvironment and cell response. Bars with shaded gradients show cell and protein responses across a range of WCAs. 


\begin{tabular}{|c|c|c|c|}
\hline Functionality & Properties & Protein response & Cell response \\
\hline Carboxyl & Polar, acidic & Fn binding of both $\alpha 5 \beta 1$ and $\alpha \mathrm{V} \beta 3 .{ }^{96}$ & Chondrogenesis. ${ }^{122}$ \\
\hline Phosphate & Polar, acidic & - & Osteogenesis. ${ }^{137}$ \\
\hline Silanol & Polar & Increased BSA binding, deformation vs. $\mathrm{CH}_{3}{ }^{95}$ & - \\
\hline Hydroxyl & Polar & $\begin{array}{l}\text { Fn selective binding of } \alpha 5 \beta 1 \text { integrin. }{ }^{96} \\
\text { Increased BSA binding, deformation } v s . \mathrm{CH}_{3} \text {. }\end{array}$ & $\begin{array}{l}\text { Osteoblastic differentiation. }{ }^{96,138} \\
\text { Chondrogenesis. }{ }^{133}\end{array}$ \\
\hline Sulphone & Polar & - & Fibrogenesis. ${ }^{130}$ \\
\hline Bromine & Polar & - & HASC Adipogenic differentiation. ${ }^{139}$ \\
\hline Amino & Polar, basic & Fn selective binding of $\alpha 5 \beta 1$ integrin. ${ }^{96}$ & $\begin{array}{l}\text { Osteoblastic differentiation. }{ }^{96} \\
\text { hADSC osteogenesis, high growth. }{ }^{139} \\
\text { MSC differentiation. }{ }^{140} \\
\text { Mesenchymal population loss. }{ }^{141} \\
\text { MSC osteogenesis. }{ }^{133,138} \\
\text { Adipogenesis. }{ }^{138}\end{array}$ \\
\hline Thiol & Non-polar & - & Chondrogenesis. ${ }^{139}$ \\
\hline Silane & Non-polar & - & Osteogenesis. ${ }^{124}$ \\
\hline Methyl & Aliphatic & Increased $\mathrm{Fb}$ deformation $v s . \mathrm{SiOH} .{ }^{136}$ & $\begin{array}{l}\text { MSC phenotype maintenance. }{ }^{140} \\
\text { HASC low growth. }{ }^{139}\end{array}$ \\
\hline t-Butyl & Aliphatic & - & Adipogenesis. ${ }^{137}$ \\
\hline Phenyl & Aromatic & - & Chondrogenesis. ${ }^{139}$ \\
\hline
\end{tabular}

Early studies revealed how functional variations on model surfaces $\left(-\mathrm{OH},-\mathrm{NH}_{2},-\mathrm{COOH}, \mathrm{CH}_{3}\right)$ influenced the adsorption kinetics of key proteins (e.g. fibronectin), and protein characteristics upon binding (e.g. availability of integrin binding sites due to fibronectin refolding on adsorption) ${ }^{96}$. Protein binding responses were related to subsequent cell responses (e.g. differentiation of immature osteoblasts) ${ }^{96}$. That surface chemistry modifies protein conformation has been further explored and, although differential responses continue to be observed, questions remain as to how initial surface chemistry sustains cell differentiation over extended periods ${ }^{138}$. For example, in a 3D PEG-hydrogel environment, MSCs have been shown to differentiate via adipogenic or osteogenic pathways on t-butyl and phosphate functionalized surfaces respectively 137. Furthermore, poly(lactic-co-glycolic acid) and PEG400 polymer microspheres (100-300 micron) with varying functionality $\left(-\mathrm{OH},-\mathrm{NH}_{2},-\mathrm{COOH}, \mathrm{CH}_{3}\right)$ have been shown to induce osteogenesis $\left(-\mathrm{NH}_{2}\right)$ and chondrogenesis $(-\mathrm{OH})$ in MSCs ${ }^{133}$. 
Curran et al. (2006) showed that, of several functionalities tested (bare glass, - $\mathrm{OH},-\mathrm{NH}_{2}$, $\left.\mathrm{COOH}, \mathrm{CH}_{3}, \mathrm{SiH}\right), \mathrm{MSCs}$ were maintained (bare glass, $\left.\mathrm{CH}_{3}\right)$ or osteogenesis $\left(-\mathrm{NH}_{2}, \mathrm{SiH}\right)$ or chondrogenesis induced (-OH, $-\mathrm{COOH})$. The role of $\mathrm{CH}_{3}$ functionality was further explored with the added dimension of varying number (1-3 $\mathrm{CH}_{3}$ groups per silane) and alkyl chain length ( $8 \&$ 18 carbon). The surfaces influenced fibroblast growth factor release which increased for dichlorodimethylsilane surfaces and resulted in lower expression of MSC markers. Conversely, dithyloctylsilane-modified surfaces increased MSC marker expression ${ }^{142}$. The work further examined the role of topology and functionality, and demonstrated that islands of $65-70 \mathrm{~nm} \varnothing$ with a pitch of $280 \mathrm{~nm}$ was optimal for cell attachment ${ }^{140}$. The mechanism for this response was attributed to the requirement of RGD spacing of $>70 \mathrm{~nm}$ for effective cell attachment and spreading ${ }^{140}$. Such studies demonstrate the importance of the collective local environment, as the medium and surface interact to provide an environment that facilitates a given response. This can be extended to the point of identifying properties with potential application in tissue culture and biomaterial design ${ }^{91,133}$.

4.3 Limitations of Existing Studies: Our understanding of material-induced responses revolves around two themes which relate to two types of surface treatment. Topological studies favor mechanotransduction (often under-emphasizing the chemical nature of the material explored), whereas studies based on chemical modification emphasize differential adsorption of proteins or other biomolecular cues. The mechanistic processes (protein adsorption, focal adhesion, cell tensioning etc.) all appear to form part of the same overarching mechanism mechanotransduction ${ }^{143}$. Although individual studies justifiably highlight particular elements of a wider system, attempts to unify the separate components of mechanotransduction is perhaps missing from current studies. 
Although we have a reasonable understanding of what fundamental topological and chemical features can achieve in culture, we are still some way from a comprehensive understanding of how material properties influence the cell, the mechanisms in action and how material generated environments can be formed. Key questions include how the density of functional groups influences responses and the relative influence of the individual properties of a material presenting several different attributes (e.g. different functionalities and varying topology with functionality) effect a response, though this work has started ${ }^{128,129,140}$. Topology and surface chemistry are not universally studied in a well-controlled manner due to material-specific challenges in processing e.g. processing of metals such as the titanium alloys used routinely in the clinic. However, existing studies on these metals do show that variation of material properties influences cell response ${ }^{144,145}$. Identifying how material cues in 2D platforms translate into 3D platforms is another key area and, ultimately, a predictive understanding of how small changes in surface property such as the orientation of chemical groups etc. influence protein and cell response is required.

\subsection{A Perspective on the Future of Tissue Culture Materials:}

To remain relevant, tissue culture must continue to improve in order to better represent the cells, organs, biological processes and pathologies that it tries to model. Improvements are being simultaneously derived from three general directions; improved cell lines, improved media and new materials/technologies to support cell expansion/maintenance. However, increasing the cost and complexity of tissue culture acts as a barrier to uptake, and innovative new materials can be proprietary and poorly understood in comparison to existing materials. 
Developing materials for biomedical applications which incorporate active biological components is a growing area. While offering great potential, cautionary cases have appeared, in that high doses of powerful biological agents (e.g. bone morphogenetic protein 2), combined with an incomplete understanding of biomolecule-biomaterial affinity have resulted in a negative outcome for some patients such as uncontrolled ectopic calcification ${ }^{146}$. Although many studies use transformative media, materials-based technologies have started to emphasize the advantage that they have in being able to achieve responses without the addition of bioactive molecules ${ }^{10}$, ${ }^{140}$. As technologies manipulating cell and tissue development become more widely applied in vivo, the risk of uncontrolled proliferative or transformative events becomes a concern. However, the potential of materials to form tailored self-assembling (and ideally self-limiting) microenvironments in concert with the ready supply of biomolecules and tissue already available within the body could have great potential. In order to further this approach, studies to understand long-range effects; e.g. how material based cues can propagate to cells beyond the immediate influence of the surface generated microenvironment are required.

With regard to the area of tailored local microenvironments, these may be particularly useful for better understanding the differences between diseased and normal tissue. A concept that has been given considerable importance in cancer research is the effect of the local microenvironment on the pathogenesis of cancer and associated metastasis ${ }^{147}$. Materials Science, via our ability to finely control the surface and its associations with biomolecules such as proteins in the culture environment, offers considerable potential for answering these questions.

\section{AUTHOR INFORMATION}

\section{Corresponding Author}


*Email: carole.perry@ntu.ac.uk

\title{
Author Contributions
}

The manuscript was written through contributions of all authors. All authors have given approval to the final version of the manuscript.

\section{Notes}

The authors declare no competing financial interest.

\section{ACKNOWLEDGMENT}

The authors would also like to acknowledge the financial support of the John and Lucille van Geest Foundation and the Healthcare and Bioscience iNet, an ERDF-funded initiative managed by Medilink East Midlands.

\begin{abstract}
ABBREVIATIONS
3Rs, replacement, reduction and refinement principles; ANSC(s), adult neural stem cell(s); BAEC(s), bovine aortic endothelial cell(s), BSA, bovine serum albumin; CAMs, cell adhesion molecules; $\mathrm{CHO}$, Chinese hamster oocytes; ECM, extracellular matrix; Fn, fibronectin; Fb, fibrinogen; hADSC(s), human adipose stem cell(s); hESC(s), human embryonic stem cell(s); MSC(s), mesenchymal stem cell(s); NSC(s), neural stem/progenitor cell(s); PEG, polyethylene glycol; RBM, rat bone marrow; RGD, arginylglycylaspartic acid; SAM, self-assembled monolayer; TCPS, tissue culture polystyrene; WCA, water contact angle.
\end{abstract}

\section{REFERENCES}


1. Abercrombie, M. Ross Granville Harrison. 1870-1959. Biogr. Mem. Fellows R. Soc. 1961, 7, 110-126, DOI: 10.1098/rsbm.1961.0009.

2. Mazur, P. Cryobiology: The freezing of biological systems. Science 1970, 168, 939-949, DOI: $10.1126 /$ science.168.3934.939.

3. Stepanenko, A. A.; Kavsan, V. M. Immortalization and malignant transformation of eukaryotic cells. Cytol. Genet. 2012, 46, 96-129, DOI: 10.3103/S0095452712020041.

4. Badylak, S. F.; Freytes, D. O.; Gilbert, T. W. Extracellular matrix as a biological scaffold material: Structure and function. Acta Biomater. 2009, 5, 1-13, DOI: 10.1016/j.actbio.2008.09.013.

5. Kimlin, L. C.; Casagrande, G.; Virador, V. M. In vitro three-dimensional (3D) models in cancer research: an update. Mol. Carcinog. 2011, 52, 167-182, DOI: 10.1002/mc.21844.

6. Gillet, J-P.; Calcagno, A. M,; Varma, S.; Marino, M.; Green, L. J.; Vora, M. I.; Patel, C.; Orina, J. N.; Eliseeva, T. A.; Singal, V.; Padmanabhan, R.; Davidson, B.; Ganapathi, R.; Sood, A. K.; Rueda, B. R.; Ambudkar, S. V.; Gottesmana, M. M. Redefining the relevance of established cancer cell lines to the study of mechanisms of clinical anticancer drug resistance. Proc. Natl. Acad. Sci. U. S. A. 2011, 108, 18708-18713, DOI: 10.1073/pnas.1111840108.

7. Korch, C.; Spillman, M. A.; Jackson, T. A.; Jacobsen, B. M.; Murphy, S. K.; Lessey, B. A.; Jordan, V. C.; Bradford, A. P. DNA profiling analysis of endometrial and ovarian cell lines reveals misidentification, redundancy and contamination. Gynecol. Oncol. 2012, 127, 241-248, DOI: 10.1016/j.ygyno.2012.06.017. 
8. Astashkina, A.; Mann, B.; Grainger, D. W. A critical evaluation of in vitro cell culture models for high-throughput drug screening and toxicity. Pharmacol. Ther. 2012, 134, 82106, DOI: 10.1016/j.pharmthera.2012.01.001.

9. Gillet, J-P.; Varma, S.; Gottesman, M. M. The clinical relevance of cancer cell lines. $J$. Natl. Cancer Inst. 2013, 105, 452-458, DOI: 10.1093/jnci/djt007.

10. McMurray, R. J.; Gadegaard, N.; Tsimbouri, P. M.; Burgess, K. V.; McNamara, L. E.; Tare, R.; Murawski, K.; Kingham, E.; Oreffo, R. O.; Dalby, M. J. Nanoscale surfaces for the long-term maintenance of mesenchymal stem cell phenotype and multipotency. Nat. Mater. 2011, 10, 637-644, DOI: 10.1038/nmat3058.

11. Hutchinson, L., Kirk, R. High drug attrition rates - where are we going wrong? Nat. Rev. Clin. Oncol. 2011, 8, 189-190, DOI: 10.1038/nrclinonc.2011.34.

12. Begley, C. G.; Ellis, L. M. Drug development: Raise standards for preclinical cancer research. Nature 2012, 483, 531-533, DOI: 10.1038/483531a.

13. Hünig, T. The storm has cleared: lessons from the CD28 superagonist TGN1412 trial. Nat. Rev. Immunol. 2012, 12, 317-318, DOI: 10.1038/nri3192.

14. Lee, S.; Tang, C.; Rao, M. S.; Weissman, I. L.; Wu, J. C. Tumorigenicity as a clinical hurdle for pluripotent stem cell therapies. Nat. Med. 2013, 19, 998-1004, DOI: 10.1038/nm.3267. 
15. Smoliga, J. M, Vang, O, Baur, J. A. Challenges of translating basic research into therapeutics: resveratrol as an example. J. Gerontol. A Biol. Sci. Med. Sci. 2012, 67, 158167, DOI: 10.1093/gerona/glr062.

16. Mak, I. W.; Evaniew, N.; Ghert, M. Lost in translation: animal models and clinical trials in cancer treatment. Am. J. Transl. Res. 2014, 6, 114-118

17. Flecknell, P. Replacement, reduction and refinement. ALTEX 2002, 19, 73-78

18. Hotchin, J. E. Use of methyl cellulose gel as a substitute for agar in tissue-culture overlays. Nature 1955, 175, 352, DOI: 10.1038/175352a0.

19. Michalopoulos, G.; Pitot, H. C. Primary culture of parenchymal liver cells on collagen membranes: morphological and biochemical observations. Exp. Cell. Res. 1975, 94, 7078, DOI: $10.1016 / 0014-4827(75) 90532-7$.

20. Shukla, S. C.; Singh, A.; Pandey, A. K.; Mishra, A. Review on production and medical applications of $\varepsilon$-polylysine. Biochem. Eng. J. 2012, 65, 70-81, DOI: 10.1016/j.bej.2012.04.001.

21. Yang, S., Pilgaard, L., Chase, L. G., Boucher, S., Vemuri, M. C., Fink, T., Zachar, V. Defined xenogeneic-free and hypoxic environment provides superior conditions for longterm expansion of human adipose-derived stem cells. Tissue Eng. Part C 2012, 18, 593602, DOI: 10.1089/ten.TEC.2011.0592.

22. Hunt, N. C., Grover, L. M. Cell encapsulation using biopolymer gels for regenerative medicine. Biotechnol Lett. 2010, 32, 733-742, DOI: 10.1007/s10529-010-0221-0. 
23. Eiraku, M, Sasai, Y. Mouse embryonic stem cell culture for generation of threedimensional retinal and cortical tissues. Nat. Protoc. 2011, 7, 69-79, DOI: 10.1038/nprot.2011.429.

24. Underwood, P. A.; Bennett, F. A. A comparison of the biological activities of the celladhesive proteins vitronectin and fibronectin. J. Cell Sci. 1989, 93, 641-649

25. Eagle, H. Nutritional needs of mammalian cells in tissue culture. Science 1955, 122, 501504, DOI: 10.1126/science.122.3168.501.

26. Lam, M. T., Longaker, M. T. Comparison of several attachment methods for human iPS, embryonic and adipose-derived stem cells for tissue engineering. J. Tissue Eng. Regener. Med. 2012, 6, s80-s86, DOI: 10.1002/term.1499.

27. Kleinman, H. K.; Martin, G. R. Matrigel: Basement membrane matrix with biological activity. Semin. Cancer Biol. 2005, 15, 378-386, DOI:10.1016/j.semcancer.2005.05.004.

28. Knox, P., Wells, P. Cell adhesion and proteoglycans. I. The effect of exogenous proteoglycans on the attachment of chick embryo fibroblasts to tissue culture plastic and collagen. J. Cell Sci. 1979, 40, 77-88

29. Serra, M.; Brito, C.; Correia, C.; Alves, P. M. Process engineering of human pluripotent stem cells for clinical application. Trends Biotechnol. 2012, 30, 350-359, DOI: 10.1016/j.tibtech.2012.03.003.

30. Ramsey, W. S.; Hertl, W.; Nowlan, E. D.; Binkowski, N. J. Surface treatments and cell attachment. In Vitro 1984, 20, 802-808, DOI: 10.1007/BF02618296. 
31. Curtis, A. S.; Forrester, J. V.; McInnes, C.; Lawrie, F. Adhesion of cells to polystyrene surfaces. J. Cell Biol. 1983, 97, 1500-1506

32. Evans, M. D. M.; Steele, J. G. Multiple attachment mechanisms of corneal epithelial cells to a polymer - cells can attach in the absence of exogenous adhesion proteins through a mechanism that requires microtubules. Exp. Cell Res. 1997, 233, 88-98, DOI: $10.1006 /$ excr.1997.3523.

33. Evans, M. D. M.; Steele, J. G. Polymer surface chemistry and a novel attachment mechanism in corneal epithelial cells. J. Biomed. Mater. Res. 1998, 40, 621-30, DOI: 10.1002/(SICI)1097-4636(19980615)40:4<621::AID-JBM14>3.0.CO;2-I.

34. Steele, J. G., Dalton, B. A., Johnson, G., Underwood, P. A. Adsorption of fibronectin and vitronectin onto Primaria and tissue culture polystyrene and relationship to the mechanism of initial attachment of human vein endothelial cells and BHK-21 fibroblasts. Biomaterials 1995, 16, 1057-1067, DOI: 10.1016/0142-9612(95)98901P.

35. Becton, Dickinson \& Company. Defined cell culturing surfaces and methods of use. 2010, US 20100021998A1

36. Rimann, M.; Graf-Hausner, U. Synthetic 3D multicellular systems for drug development. Curr. Opin. Biotechnol. 2012, 23, 1-7, DOI: 10.1016/j.copbio.2012.01.011.

37. Kosovsky, M. Accelerating R\&D of cell-based therapies. Genet. Eng. Biotechnol. News 2012, 32, 56-57, DOI: 10.1089/gen.32.17.24. 
38. Kartner, N.; Yao, Y.; Li, K.; Crasto, G. J.; Datti, A.; Manolson, M. F. Inhibition of osteoclast bone resorption by disrupting vacuolar $\mathrm{H}^{+}$-ATPase $a 3$-B2 subunit interaction. J. Biol. Chem., 2010, 285, 37476-37490, DOI: 10.1074/jbc.M110.123281.

39. Tibbitt, M. W.; Anseth, K. S. Hydrogels as extracellular matrix mimics for 3D cell culture. Biotechnol. Bioeng. 2009, 103, 655-663, DOI: 10.1002/bit.22361.

40. Frohbergh, M. E.; Katsman, A.; Botta, G. P.; Lazarovici, P.; Schauer, C. L.; Wegst, U. G. K.; Lelkes, P. I. Electrospun hydroxyapatite-containing chitosan nanofibers crosslinked with genipin for bone tissue engineering. Biomaterials, 2012, 33, 9176-9178, DOI: 10.1016/j.biomaterials.2012.09.009.

41. Kelm, J. M.; Timmins, N. E.; Brown, C. J.; Fussenegger, M.; Nielsen, L. K. Method for generation of homogeneous multicellular tumor spheroids applicable to a wide variety of cell types. Biotechnol. Bioeng. 2003, 83, 173-180, DOI: 10.1002/bit.10655.

42. Lee, J.; Abdeen, A. A.; Zhang, D.; Kilian, K. A. Directing stem cell fate on hydrogel substrates by controlling cell geometry, matrix mechanics and adhesion ligand

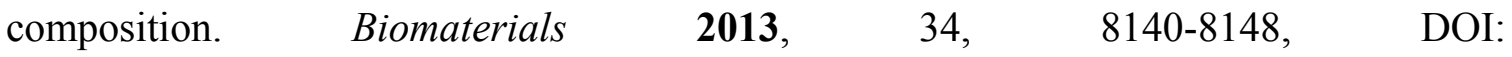
10.1016/j.biomaterials.2013.07.074.

43. Low, S. P.; Williams, K. A.; Canham, L. T.; Voelcker, N. H. Evaluation of mammalian cell adhesion on surface-modified porous silicon. Biomaterials 2006, 27, 4538-4546, DOI:10.1016/j.biomaterials.2006.04.015. 
44. Jin, S.; Yao, H.; Weber, J. L.; Melkoumian, Z. K.; Ye, K. A Synthetic, Xeno-free peptide surface for expansion and directed differentiation of human induced pluripotent stem cells. PLoS One 2012, e50880, DOI: 10.1371/journal.pone.0050880.

45. Hersel, U.; Claudia, D.; Horst, K. RGD modified polymers: biomaterials for stimulated cell adhesion and beyond. Biomaterials 2003, 24, 4385-4415, DOI: 10.1016/S01429612(03)00343-0.

46. Plow, E. F.; Haas, T. A.; Zhang, L.; Loftus, J.; Smith, J. W. Ligand binding to integrins. J. Biol. Chem. 2000, 275, 21785-21788, DOI: 10.1074/jbc.R000003200.

47. Kaji, H.; Camci-Unal, G.; Langer, R.; Khademhosseini, A. Engineering systems for the generation of patterned co-cultures for controlling cell-cell interactions. Biochim. Biophys. Acta 2011, 1810, 239-250, DOI: 10.1016/j.bbagen.2010.07.002.

48. Georgess, D.; Mazzorana, M.; Terrado, J.; Delprat, C.; Chamot, C.; Guasch, R. M.; Pérez-Roger, I.; Jurdic, P.; Machuca-Gayet, I. Comparative transcriptomics reveals RhoE as a novel regulator of actin dynamics in bone-resorbing osteoclasts. Mol. Biol. Cell. 2014, 25, 380-396, DOI: 10.1091/mbc.E13-07-0363.

49. Barnes, D.; Sato, G. Serum-free cell culture: a unifying approach. Cell 1980, 22, 649655, DOI: 10.1016/0092-8674(80)90540-1.

50. van der Valk, J.; Brunner, D.; De Smet, K.; Fex Svenningsen, A.; Honegger, P.; Knudsen, L. E.; Lindl, T.; Noraberg, J.; Price, A.; Scarino, M. L.; Gstraunthaler, G. Optimization of chemically defined cell culture media - replacing fetal bovine serum in 
mammalian in vitro methods. Toxicol. In Vitro 2010, 24, 1053-1063, DOI: 10.1016/j.tiv.2010.03.016.

51. Santos, E.; Harnandez, R. M.; Pedraz, J. L.; Orive, G. Novel advances in the design of three-dimensional bio-scaffolds to control cell fate: translation from $2 \mathrm{D}$ to $3 \mathrm{D}$. Curr. Trends Biotechnol., 2012, 30, 331-41, DOI: 10.1016/j.tibtech.2012.03.005.

52. Schober, A.; Fernekorn, U.; Singh, S.; Schlingloff, G.; Gebinoga, M.; Hampl, J.; Williamson, A. Mimicking the biological world: Methods for the 3D structuring of artificial cellular environments. Eng. Life Sci. 2013, 13, 352-367, DOI: 10.1002/elsc.201200088.

53. Lutolf, M. P. Biomaterials: spotlight on hydrogels. Nature Mater. 2009, 8, 451-453, DOI: $10.1038 / \mathrm{nmat} 2458$.

54. Baker, B. M.; Chen, C. S. Deconstructing the third dimension: how 3D culture microenvironments alter cellular cues. J. Cell Sci. 2012, 125, 3015-3024, DOI: 10.1242/jcs.079509.

55. Page, H.; Flood, P.; Reynaud, E. G. Three-dimensional tissue cultures: current trends and beyond. Cell Tissue Res. 2013, 352, 123-131, DOI: 10.1007/s00441-012-1441-5.

56. Tibbitt, M. W.; Anseth, K. S. Hydrogels as extracellular matrix mimics for 3D cell culture. Biotechnol. Bioeng. 2009, 103, 655-663, DOI: 10.1002/bit.22361. 
57. Fennema, E.; Rivron, N.; Rouwkema, J.; van Blitterswijk, C.; de Boer, J. Spheroid culture as a tool for creating 3D complex tissues. Trends Biotechnol. 2013, 31, 108-115, DOI: $10.1016 /$ j.tibtech.2012.12.003.

58. Hutmacher, D.W.; Loessner, D.; Rizzi, S.; Kaplan, D. L.; Mooney, D. J.; Clement, J. A. Can tissue engineering concepts advance tumor biology research? Trends Biotechnol. 2010, 28, 125-133, DOI: 10.1016/j.tibtech.2009.12.001.

59. Gibbons, M. C.; Foley, M. A.; Cardinal, K. O. Thinking inside the box: keeping tissueengineered constructs in vitro for use as preclinical models. Tissue Eng. Part B Rev. 2013, 19, 14-30, DOI: 10.1089/ten.TEB.2012.0305.

60. Wilson, C. J.; Clegg, R. E.; Leavesley, D. I.; Pearcy, M. J. Mediation of biomaterial-cell interactions by adsorbed proteins: a review. Tissue Eng. 2005, 11, 1-18, DOI: 10.1089/ten.2005.11.1.

61. Mattila, P. K.; Lappalainen, P. Filopodia: molecular architecture and cellular functions. Nat. Rev. Mol. Cell Biol. 2008, 9, 447-454, DOI:10.1038/nrm2406.

62. Olson, M.F.; Sahai, E. The actin cytoskeleton in cancer cell motility. Clin. Exp. Metastasis 2009, 2, 273-287, DOI: 10.1007/s10585-008-9174-2.

63. Valentijn, A. J.; Zoug, N.; Gilmore, A. P. Anoikis. Biochem. Soc. Trans. 2004, 32, 421425, DOI: $10.1042 / \mathrm{bst} 0320421$.

64. Sakamoto, S.; Kyprianou, N. Targeting anoikis resistance in prostate cancer metastasis. JMAM 2010, 1, 205-214, DOI: 10.1016/j.mam.2010.02.001. 
65. Gilmore, A. P.; Romer, L. H. (1996). Inhibition of focal adhesion kinase (FAK) signaling in focal adhesions decreases cell motility and proliferation. Mol. Biol. Cell, MBoC 1996, 7, 1209-1224, DOI: 10.1091/mbc.7.8.1209.

66. Larsen, M., Artym, V. V., Green, J. A., Yamada, K. M. The matrix reorganized: extracellular matrix remodeling and integrin signaling. Curr. Opin. Cell Biol. 2006, 463471, DOI: 10.1016/j.ceb.2006.08.009.

67. Giancotti, F. G., Ruoslahti, E. Integrin signaling. Science 1999, 285, 1028-1032, DOI: 10.1126/science.285.5430.1028.

68. Li, L.; Bennett, S. A. L.; Wang, L. Role of E-cadherin and other cell adhesion molecules in survival and differentiation of human pluripotent stem cells. Cell Adh. Migr. 2012, 6, 59-70, DOI: 10.4161/cam.19583.

69. Schwartz, M. A.; Simone, D. Cell adhesion receptors in mechanotransduction. Curr. Opin. Cell Biol. 2008, 20, 551-556, DOI: 10.1016/j.ceb.2008.05.005.

70. Iskratsch, T.; Wolfenson, H.; Sheetz, M. P. Appreciating force and shape - the rise of mechanotransduction in cell biology. Nat. Rev. Mol. Cell Biol. 2014, 15, 825-833, DOI: $10.1038 / \mathrm{nrm} 3903$.

71. DuFort, C. C.; Paszek, M. J.; Weaver, V. M. Balancing forces: architectural control of mechanotransduction. Nat. Rev. Mol. Cell Biol. 2011, 12, 308-319, DOI: $10.1038 / \mathrm{nrm} 3112$. 
72. Dupont, S.; Morsut, L.; Aragona, M.; Enzo, E.; Giulitti, S.; Cordenonsi, M.; Zanconato, F.; Le Digabel, J.; Forcato, M.; Bicciato, S.; Elvassore, N.; Piccolo, S. Role of YAP/TAZ in mechanotransduction. Nature 2011, 474, 179-183, DOI: 10.1038/nature10137.

73. Dupont, S. Role of YAP/TAZ in cell-matrix adhesion-mediated signalling and mechanotransduction. Exp. Cell Res. 2015, 15, 30139-30147, DOI: 10.1016/j.yexcr.2015.10.034.

74. Hsu, H. J.; Lee, C. F.; Locke, A.; Vanderzyl, S. Q.; Kaunas, R. Stretch-induced stress fiber remodeling and the activations of JNK and ERK depend on mechanical strain rate, but not FAK. PLoS One 2010, 5, e12470, DOI: 10.1371/journal.pone.0012470.

75. Wong, V. W.; Longaker, M. T.; Gurtner, G. C.. Soft tissue mechanotransduction in wound healing and fibrosis. Semin. Cell. Dev. Biol. 2012, 23, 981-986, DOI: 10.1016/j.semcdb.2012.09.010.

76. García J. R.; García A. J. Cellular mechanotransduction: sensing rigidity. Nat. Mater. 2014, 13, 539-540, DOI: 10.1038/nmat3996.

77. Dalby, M. J.; Gadegaard, N.; Oreffo, R. O. Harnessing nanotopography and integrinmatrix interactions to influence stem cell fate. Nat. Mater. 2014, 13, 558-569, DOI: 10.1038/nmat3980.

78. Schwarz, U. S.; Gardel, M. L. United we stand: integrating the actin cytoskeleton and cell-matrix adhesions in cellular mechanotransduction. J. Cell Sci., 2012, 125, 30513060, DOI: $10.1242 /$ jcs.093716. 
79. Ruoslahti, E.; Pierschbacher, M. D. New perspectives in cell adhesion: RGD and integrins. Science 1987, 238, 491-497, DOI: 10.1126/science.2821619.

80. Kilian, K. A., Mrksich, M. Directing stem cell fate by controlling the affinity and density of ligand-receptor interactions at the biomaterials interface. Angew. Chem. Int. Ed. Engl. 2012, 51, 4891-4895, DOI: 10.1002/anie.201108746.

81. Chollet, C.; Chanseau, C.; Remy, M.; Guignandon, A.; Bareille, R.; Labrugere, C.; Bordenave, L.; Durrieu, M-C. The effect of RGD density on osteoblast and endothelial cell behaviour on RGD-grafted polyethylene terephthalate surfaces. Biomaterials 2009, 30, 711-720, DOI: 10.1016/j.biomaterials.2008.10.033.

82. Lee, K. Y.; Alsberg, E.; Hsiong, S.; Comisar, W.; Linderman, J.; Ziff, R.; Mooney, D. Nanoscale adhesion ligand organization regulates osteoblast proliferation and differentiation. Nano Lett. 2004, 4, 1501-1506, DOI: 10.1021/n10493592.

83. Oakes, P. W., Gardel, M. L. Stressing the limits of focal adhesion mechanosensitivity. Curr. Opin. Cell Biol. 2014, 30, 68-73, DOI: 10.1016/j.ceb.2014.06.003.

84. Nicklin, M., Rees, R. C., Pockley, A. G., Perry, C. C. Development of an hydrophobic fluoro-silica surface for studying homotypic cancer cell aggregation-disaggregation as a single dynamic process in vitro. Biomater. Sci. 2014, 2, 1486-1496, DOI: 10.1039/C4BM00194J.

85. Sun, M., Deng, J., Tang, Z., Wu, J., Li, D., Chen, H., Gao. A correlation study of protein adsorption and cell behaviors on substrates with different densities of PEG chains. Colloids Surf. B 2014, 122, 134-142, DOI: 10.1016/j.colsurfb.2014.06.041. 
86. Gumbiner, B. M. Cell adhesion: review the molecular basis of tissue architecture and morphogenesis. Cell, 1996, 84, 345-357, DOI: 10.1016/S0092-8674(00)81279-9.

87. Bendas, G., Borsig, L. Cancer cell adhesion and metastasis: selectins, integrins, and the inhibitory potential of heparins. Int. J. Cell Biol. 2012, 2012:676731, DOI: $10.1155 / 2012 / 676731$.

88. Lee J., Abdeen A. A., Zhang D., Kilian K. A. Directing stem cell fate on hydrogel substrates by controlling cell geometry, matrix mechanics and adhesion ligand composition. $\quad$ Biomaterials $2013, \quad 34, \quad 8140-8148, \quad$ DOI: 10.1016/j.biomaterials.2013.07.074.

89. Gattazzo, F., Urciuolo, A., Bonaldo, P. Extracellular matrix: a dynamic microenvironment for stem cell niche. Biochim. Biophys. Acta 2014, 1840, 2506-2519, DOI: 10.1016/j.bbagen.2014.01.010.

90. Badylak, S. F.; Weiss, D. J.; Caplan, A.; Macchiarini, P. Engineered whole organs and complex tissues. Lancet 2012, 379, 943-952, DOI: 10.1016/S0140-6736(12)60073-7.

91. Roach, P.; Eglin, D.; Rohde, K.; Perry. C. C. Modern biomaterials: a review - bulk properties and implications of surface modifications. J. Mater. Sci. Mater. Med. 2007, 18, 1263-1277, DOI: 10.1007/s10856-006-0064-3

92. Hirsh, S. L.; McKenzie, D. R.; Nosworthy, N. J.; Denman, J. A.; Sezerman, O. U.; Bilek, M. M. The Vroman effect: competitive protein exchange with dynamic multilayer protein aggregates. Colloids Surf. $B$ Biointerfaces 2013, 103, 395-404, DOI: 10.1016/j.colsurfb.2012.10.039. 
93. Frantz, C.; Stewart, K. M.; Weaver, V. M. The extracellular matrix at a glance. J. Cell Sci. 2010, 123, 4195-4200, DOI: $10.1242 /$ jcs.023820.

94. Yang, J., Mei, Y., Hook, A. L., Taylor, M., Urquhart, A. J., Bogatyrev, S. R., Langer, R., Anderson, D. G., Davies, M. C., Alexander, M. R. Polymer surface functionalities that control human embryoid body cell adhesion revealed by high throughput surface characterization of combinatorial material microarrays. Biomaterials 2010, 31, 88278838, DOI: 10.1016/j.biomaterials.2010.08.028.

95. Roach, P.; Farrar, D.; Perry, C.C. Surface tailoring for controlled protein adsorption: effect of topography at the nanometer scale and chemistry. J. Am. Chem. Soc. 2006, 128, 3939-3945, DOI: $10.1021 / \mathrm{ja} 056278 \mathrm{e}$.

96. Keselowsky, B. G.; Collard, D. M.; García, A. J. Integrin binding specificity regulates biomaterial surface chemistry effects on cell differentiation. Proc. Natl. Acad. Sci. U. S. A. 2005, 102, 5953-5957, DOI: 10.1073/pnas.0407356102.

97. Slater, J. C. Atomic radii in crystals. J. Chem. Phys. 1964, 41, 3199-3205, DOI: 10.1063/1.1725697.

98. Wenzel, R. N. Resistance of solid surfaces to wetting by water. Ind. Eng. Chem. 1936, 28, 988-994, DOI: 10.1021/ie50320a024.

99. McHale, G.; Shirtcliffe, N. J.; Newton, M. I. Super-hydrophobic and super-wetting surfaces: analytical potential? Analyst 2004, 129, 284-287, DOI: 10.1039/B400567H. 
100. Battiston, K. G., McBane, J. E., Labow, R. S., Paul Santerre, J. Differences in protein binding and cytokine release from monocytes on commercially sourced tissue culture polystyrene. Acta Biomater. 2012, 8, 89-98, DOI: 10.1016/j.actbio.2011.09.015.

101. Roach, P.; Parker, T.; Gadegaard, N.; Alexander, M. R. Surface strategies for control of neuronal cell adhesion: A review. Surf. Sci. Rep. 2010, 66, 146-173, DOI: 10.1016/j.surfrep.2010.07.001.

102. Rostam, H. M.; Singh, S.; Vrana, N. E.; Alexander, M. R.; Ghaemmaghami, A. M. Impact of surface chemistry and topography on the function of antigen presenting cells. Biomater. Sci. 2015, 3, 424-441, DOI: 10.1039/C4BM00375F.

103. Weiss, P.; Garber, B. Shape and movement of mesenchyme cells as functions of the physical structure of the medium. Contributions to a quantitative morphology. Proc. Natl. Acad. Sci. U. S. A. 1952, 38, 264-280, DOI: 10.1073/pnas.38.3.264.

104. Dalby, M. J.; Gadegaard, N.; Tare, R.; Andar, A.; Riehle, M. O.; Herzyk, P.; Wilkinson, C. D.; Oreffo, R. O. The control of human mesenchymal cell differentiation using nanoscale symmetry and disorder. Nat. Mater. 2007, 6, 997-1003, DOI: 10.1038/nmat2013.

105. Lee M. R.; Kwon, K. W.; Jung, H.; Kim, H. N.; Suh, K. Y., Kim, K.; Kim, K. S. Direct differentiation of human embryonic stem cells into selective neurons on nanoscale ridge/groove pattern arrays. Biomaterials 2010, 31, 4360-4366, DOI: 10.1016/j.biomaterials.2010.02.012. 
106. Wang, P. Y.; Li, W. T.; Yu, J.; Tsai, W. B. Modulation of osteogenic, adipogenic and myogenic differentiation of mesenchymal stem cells by submicron grooved topography. J. Mater. Sci. Mater. Med., 2012, 23, 3015-3028, DOI: 10.1007/s10856-0124748-6.

107. McMurray, R.; Dalby, M. J.; Gadegaard, N. Nanopatterned surfaces for biomedical applications in "Biomedical Engineering, Trends in Materials Science" ed. Laskovski, A. N. Chapter 16, 2011, ISBN 978-953-307-513-6.

108. Gilbert, P. M.; Havenstrite, K. L.; Magnusson, K. E.; Sacco, A.; Leonardi, N. A.; Kraft, P.; Nguyen, N. K.; Thrun, S.; Lutolf, M. P.; Blau, H. M. Substrate elasticity regulates skeletal muscle stem cell self-renewal in culture. Science 2010, 329, 1078-1081, DOI: $10.1126 /$ science.1191035.

109. Le Saux, G., Magenau, A., Böcking, T., Gaus, K., Gooding, J. J. The relative importance of topography and RGD ligand density for endothelial cell adhesion. PLoS One 2011, 6, e21869, DOI: 10.1371/journal.pone.0021869.

110. Kingham, E., White, K., Gadegaard, N., Dalby, M. J., Oreffo, R. O. Nanotopographical cues augment mesenchymal differentiation of human embryonic stem cells. Small 2013, 9, 2140-2151, DOI: 10.1002/smll.201202340.

111. Bain, L. E., Collazo, R., Hsu, S. H., Latham, N. P., Manfra, M. J., Ivanisevic, A. Surface topography and chemistry shape cellular behavior on wide band-gap semiconductors. Acta Biomater. 2014, 10, 2455-2462, DOI: 10.1016/j.actbio.2014.02.038. 
112. Selhuber-Unkel, C.; Erdmann, T.; Lopez-Garcia, M.; Kessler, H.; Schwarz, U. S.; Spatz, J. P. Cell adhesion strength is controlled by intermolecular spacing of adhesion receptors. Biophys. J. 2010, 98, 543-551, DOI: 10.1016/j.bpj.2009.11.001.

113. Christopherson, G. T.; Song, H.; Mao. H. Q. The influence of fiber diameter of electrospun substrates on neural stem cell differentiation and proliferation. Biomaterials 2009, 30, 556-564, DOI: 10.1016/j.biomaterials.2008.10.004.

114. Qi, L., Li, N., Huang, R., Song, Q., Wang, L., Zhang, Q., Su, R., Kong, T., Tang, M., Cheng, G. The effects of topographical patterns and sizes on neural stem cell behavior. PLoS One 2013, 8, e59022, DOI: 10.1371/journal.pone.0059022.

115. Dalby, M. J. Cellular response to low adhesion nanotopographies. Int. J. Nanomedicine 2007, 2, 373-381

116. Myrna, K. E., Mendonsa, R., Russell, P., Pot, S. A., Liliensiek, S. J., Jester, J. V., Nealey, P. F., Brown, D., Murphy, C. J. Substratum topography modulates corneal fibroblast to myofibroblast transformation. Invest. Ophthalmol. Vis. Sci. 2012, 53, 811816, DOI: $10.1167 /$ iovs.11-7982.

117. Komasa, S., Kusumoto, T., Taguchi, Y., Nishizaki, H., Sekino, T., Umeda, M., Okazaki, J., Kawazoe, T. Effect of nanosheet surface structure of titanium alloys on cell differentiation. J. Nanomater. 2014, 642527, 1-11, DOI: 10.1155/2014/642527.

118. Hovgaard, M. B.; Rechendorff, K.; Chevallier, J.; Foss, M.; Besenbacher, F. Fibronectin adsorption on tantalum: the influence of nanoroughness. J. Phys. Chem. B 2008, 112, 8241-8249, DOI: 10.1021/jp801103n. 
119. Rechendorff, K.; Hovgaard, M. B.; Foss, M.; Zhdanov, V. P.; Besenbacher, F. Enhancement of protein adsorption induced by surface roughness. Langmuir 2006, 22, 10885-10888, DOI: 10.1021/la0621923.

120. Dolatshahi-Pirouz, A.; Rechendorff, K.; Hovgaard, M. B.; Foss, M.; Chevallier, J.; Besenbacher, F. Bovine serum albumin adsorption on nano-rough platinum surfaces studied by QCM-D. Colloids Surf. $B$ Biointerfaces 2008, 66, 53-59, DOI: 10.1016/j.colsurfb.2008.05.010.

121. Lord M. S.; Cousins, B. G.; Doherty, P. J.; Whitelock, J. M.; Simmons, A.; Williams, R. L.; Milthorpe, B. K. The effect of silica nanoparticulate coatings on serum protein adsorption and cellular response. Biomaterials 2006, 27, 4856-4862, DOI: 10.1016/j.biomaterials.2006.05.037.

122. Johansson, F.; Carlberg, P.; Danielsen, N.; Montelius, L.; Kanje, M. Axonal outgrowth on nano-imprinted patterns. Biomaterials 2006, 27, 1251-1258, DOI: 10.1016/j.biomaterials.2005.07.047.

123. Foley, J. D.; Grunwald, E. W.; Nealey, P. F.; Murphy, C. J. Cooperative modulation of neuritogenesis by PC12 cells by topography and nerve growth factor. Biomaterials 2005, 26, 3639-3644, DOI: 10.1016/j.biomaterials.2004.09.048.

124. Curran, J. M.; Chen, R.; Hunt, J. A. The guidance of human mesenchymal stem cell differentiation in vitro by controlled modifications to the cell substrate. Biomaterials 2006, 27, 4783-4793, DOI: 10.1016/j.biomaterials.2006.05.001. 
125. Mohan, G.; Gallant, N. D. Surface chemistry gradients on silicone elastomers for high-throughput modulation of cell-adhesive interfaces. J. Biomed. Mater. Res. A 2015, 103, 2066-2076, DOI: 10.1002/jbm.a.35349.

126. Ranella, A.; Barberoglou, M.; Bakogianni, S.; Fotakis, C.; Stratakis, E. Tuning cell adhesion by controlling the roughness and wettability of 3D micro/nano silicon structures. Acta Biomater. 2010, 6, 2711-2720, DOI: 10.1016/j.actbio.2010.01.016.

127. Mei, Y., Saha, K., Bogatyrev, S. R., Yang, J., Hook, A. L., Kalcioglu, Z. I., Cho, S.-W., Mitalipova, M., Pyzocha, N., Rojas, F., van Vliet, K. J., Davies, M. C., Alexander, M. R., Langer, R., Jaenisch, R. Anderson, D. G. Combinatorial development of biomaterials for clonal growth of human pluripotent stem cells. Nat. Mater. 2010, 9, 768778, DOI: $10.1038 /$ nmat2812.

128. Yang, J., Rose, F. R. A. J., Gadegaard, N. Alexander, M. R. A high-throughput assay of cell-surface interactions using topographical and chemical gradients. Adv. Mater. 2009, 21, 300-304, DOI: 10.1002/adma.200801942.

129. Roach, P.; Parker, T.; Gadegaard, N.; Alexander, M. R. A bio-inspired neural environment to control neurons comprising radial glia, substrate chemistry and topography. Biomater. Sci. 2013, 1, 83-93, DOI: 10.1039/C2BM00060A.

130. da Costa, D. S.; Pires, R. A.; Frias, A. M.; Reis, R. L.; Pashkuleva, I. Sulfonic groups induce formation of filopodia in mesenchymal stem cells. J. Mater. Chem. 2012, 22, 7172-7178, DOI: 10.1039/C2JM15762D. 
131. Zelzer, M.; Alexander, M. R.; Russell, N. A. Hippocampal cell response to substrates with surface chemistry gradients. Acta Biomater. 2011, 12, 4120-4130, DOI: 10.1016/j.actbio.2011.07.021.

132. Mitchell, S. A.; Poulsson, A. H.; Davidson, M. R.; Emmison, N.; Shard, A. G.; Bradley, R. H. Cellular attachment and spatial control of cells using micro-patterned ultra-violet/ozone treatment in serum enriched media. Biomaterials 2004, 25, 4079-4086, DOI: 10.1016/j.biomaterials.2003.11.010.

133. Curran, J. M.; Fawcett, S.; Hamilton, L.; Rhodes, N. P.; Rahman, C. V.; Alexander, M.; Shakesheff, K.; Hunt, J. A. The osteogenic response of mesenchymal stem cells to an injectable PLGA bone regeneration system. Biomaterials 2013, 34, 93529364, DOI: 10.1016/j.biomaterials.2013.08.044.

134. Shen, Y.; Wang, G.; Huang, X.; Zhang, Q.; Wu, J.; Tang, C.; Yu, Q.; Liu, X. Surface wettability of plasma SiOx:H nanocoating-induced endothelial cells' migration and the associated FAK-Rho GTPases signalling pathways. J. R. Soc. Interface 2012, 9, 313-327, DOI: 10.1098/rsif.2011.0278.

135. Cantini, M.; Sousa, M.; Moratal, D.; Mano. J. F.; Salmerón-Sánchez, M. Nonmonotonic cell differentiation pattern on extreme wettability gradients. Biomater. Sci., 2013, 1, 202-212, DOI: 10.1039/C2BM00063F.

136. Roach, P.; Farrar, D.; Perry, C. C. Interpretation of protein adsorption: surfaceinduced conformational changes. J. Am. Chem. Soc. 2005, 127, 8168-8173, DOI: 10.1021/ja042898o. 
137. Benoit, D. S., Schwartz, M. P., Durney, A. R., Anseth, K. S. Small functional groups for controlled differentiation of hydrogel-encapsulated human mesenchymal stem cells. Nat. Mater. 2008, 7, 816-823, DOI: 10.1038/nmat2269.

138. Phillips, J. E.; Petrie, T. A.; Creighton, F. P.; García, A. J. Human mesenchymal stem cell differentiation on self-assembled monolayers presenting different surface chemistries. Acta Biomater. 2010, 6, 12-20, DOI: 10.1016/j.actbio.2009.07.023.

139. Liu, X., He, J., Zhang, S., Wang, X. M., Liu, H. Y., Cui, F. Z. Adipose stem cells controlled by surface chemistry. J. Tissue. Eng. Regen. Med. 2013, 7, 112-117, DOI: 10.1002/term.498.

140. Curran, J. M.; Stokes, R.; Irvine, E.; Graham, D.; Amro, N. A.; Sanedrin, R. G.; Jamil, H.; Hunt, J. A. Introducing dip pen nanolithography as a tool for controlling stem cell behaviour: unlocking the potential of the next generation of smart materials in regenerative medicine. Lab Chip 2010, 10, 1662-1670, DOI: 10.1039/c004149a.

141. Hickman, G. J, Rees, R. C, Boocock, D. J, Pockley, A. G, Perry, C. C. Controlling the dynamics of cell transition in heterogeneous cultures using surface chemistry. $A d v$. Healthc. Mater. 2015, 4, 593-601, DOI: 10.1002/adhm.201400525.

142. Curran, J. M.; Pu, F.; Chen, R.; Hunt, J. A. The use of dynamic surface chemistries to control MSC isolation and function. Biomaterials 2011, 32, 4753-4756, DOI: 10.1016/j.biomaterials.2011.03.045.

143. Ingber, D. E. Cellular mechanotransduction: putting all the pieces together again. FASEB J. 2006, 20, 811-827, DOI: 10.1096/fj.05-5424rev. 
144. Lin, L.; Wang, H.; Ni, M.; Rui, Y.; Cheng, T-Y.; Cheng, C-K.; Pan, X.; Li, G.; Lin, C. Enhanced osteointegration of medical titanium implant with surface modifications in micro/nanoscale structures. J. Orthopaedic Translation 2014, 2, 35-42, DOI: 10.1016/j.jot.2013.08.001.

145. Thakral, G. K.; Thakral, R.; Sharma, N.; Seth, J.; Vashisht, P. Nanosurface - The future of implants. J. Clin. Diagn. Res. 2014, 8, ZE07-ZE10, DOI: 10.7860/JCDR/2014/8764.4355.

146. Gronowicz, G.; Hurley, M. M.; Kuhn, L. T. Optimizing BMP-2-induced bone repair with FGF-2. J. Am. Acad. Orthop. Surg. 2014, 22, 677-679, DOI: 10.5435/JAAOS22-10-677.

147. Quail, D. F.; Joyce, J. A. Microenvironmental regulation of tumor progression and metastasis. Nat. Med. 2013, 19, 1423-1437, DOI: 10.1038/nm.3394. 
"For table of contents use only"

The importance and clinical relevance of surfaces in tissue culture

Graham J. Hickman, David J. Boocock†, A. Graham Pockley†, and Carole C. Perry*

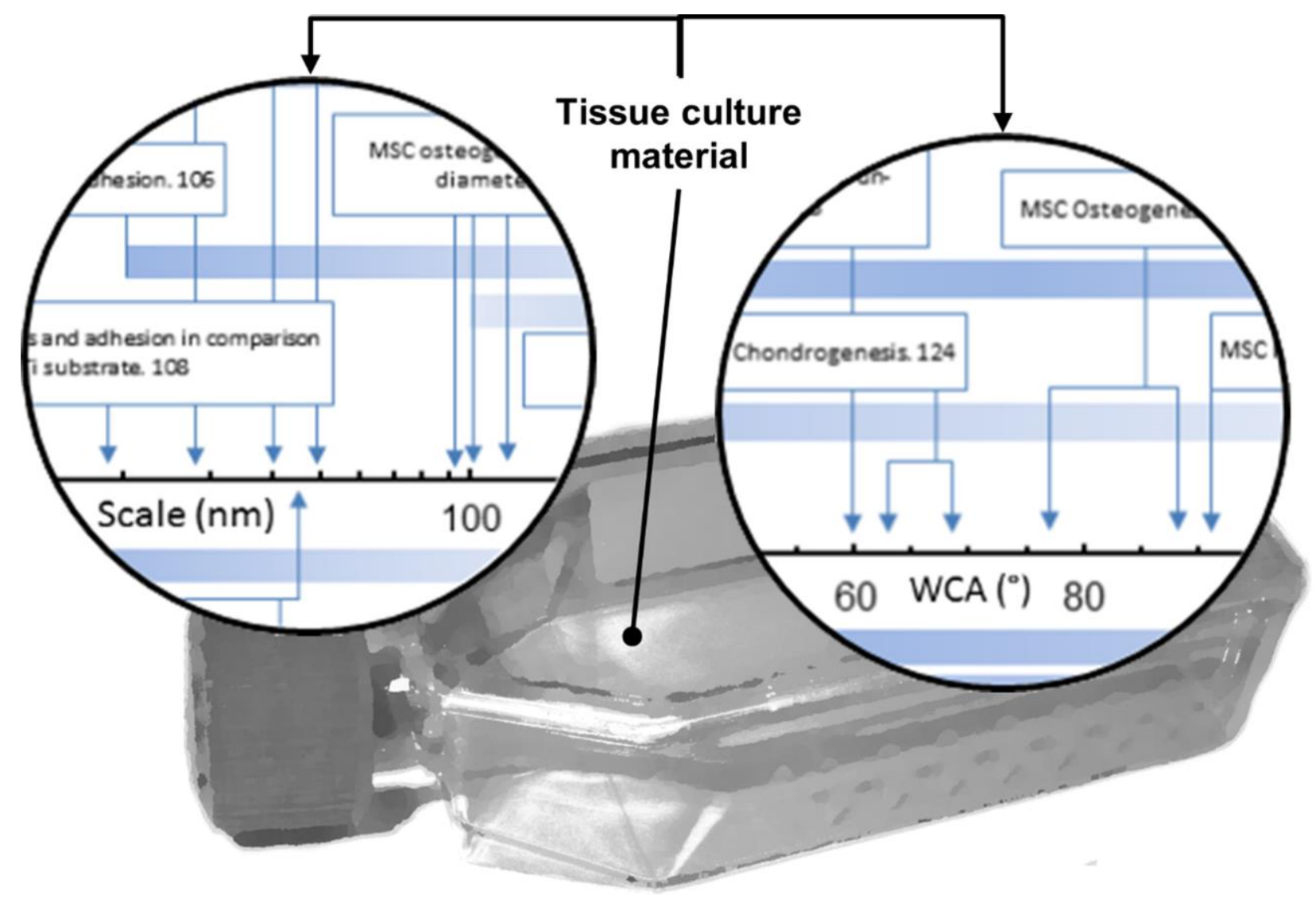

